\title{
Insect herbivory from early Permian Mitchell Creek Flats of north- central Texas: opportunism in a balanced component community
}

\author{
Sandra R. Schachat ${ }^{\mathrm{a}, \mathrm{b},{ }^{*}, \dagger}$, Conrad C. Labandeira ${ }^{\mathrm{a}-\mathrm{d}}$, Dan S. Chaney ${ }^{\mathrm{a}}$ \\ aDepartment of Paleobiology, National Museum of Natural History, Smithsonian Institution, \\ Washington, DC 20013-7012, USA \\ bepartment of Entomology, University of Maryland, College Park, MD 20742, USA \\ 'BEES Program, University of Maryland, College Park, MD 20742, USA \\ ${ }^{\mathrm{d} C o l l e g e ~ o f ~ L i f e ~ S c i e n c e s, ~ C a p i t a l ~ N o r m a l ~ U n i v e r s i t y, ~ B e i j i n g ~ 100048, ~ C h i n a ~}$ \\ *Corresponding author: Tel: +01 202 633-1382 (office), +01 202 786-2832 (fax), \\ schachatsr@si.edu \\ ${ }^{\dagger}$ Current address: Department of Biochemistry, Molecular Biology, Entomology \& Plant \\ Pathology, Mississippi State University, Starkville, MS 39762, USA
}

(C) 2015. This manuscript version is made available under the Elsevier user license http://www.elsevier.com/open-access/userlicense/1.0/ 


\begin{abstract}
The Mitchell Creek Flats locality (MCF) contains a flora from the early Permian (Cisuralian) of north-central Texas that has been qualitatively and quantitatively evaluated for insect herbivory. The level of herbivory is average for a middle Cisuralian flora from this region, although there is a relatively modest number of specimens. Three ecological features of this deposit are noteworthy in the context of the larger plant-insect interaction trends that have been studied across the region. First is a well-balanced distribution across the MCF flora of the five functional feeding groups (FFGs) of external foliage feeding, piercing and sucking, oviposition, galling, and seed predation. These five FFGs encompass 22 discrete insect-mediated damage types (DTs) that indicate a variety of generalized and specialized herbivory. Second is the elevated incidence and diversity of seven gall DTs, indicating an arid environment. Third is the pattern of opportunistic herbivory on the cycadophyte Taeniopteris spp., the single, overwhelmingly dominant host that represents $47.5 \%$ of all foliage, $56.9 \%$ of all interactions, and 16 of the 22 DTs. This distribution of insect-mediated damage suggests a diverse community of opportunistic, generalized and specialized insect herbivores, including a guild of xeric-adapted gallers engaged in a variety of feeding styles that overwhelmingly targeted Taeniopteris spp. as a host plant. This characterization is consistent with an opportunistic herbivory strategy and supports Feeny's apparency hypothesis, in which the most conspicuous, accessible plant at a site is disproportionately and most extensively herbivorized.
\end{abstract}

Keywords: Apparency hypothesis; Cisuralian; Functional feeding group; Galling; Late Paleozoic;

\title{
Taeniopteris
}

\section{Introduction}

The ecological crisis and major extinction event that occurred at the boundary between the Permian and Triassic Periods (P-Tr) is associated with the decline of the Paleozoic Insect Fauna, 
facilitating the subsequent diversification of the Modern Insect Fauna (Labandeira, 2005). Although significant lineage turnover occurred at this boundary, characterized by large-scale extinctions of the older fauna and originations of the subsequent fauna (Dmitriev and Zherikhin, 1988; Labandeira and Sepkoski, 1993; Jarzembowski and Ross, 1996), a number of lineages did survive. Many of the survivors were herbivore clades that diversified during the Mesozoic and have continued to play important roles in plant-insect interactions to this day. The Permian Period was an important early phase for this transition: clades of the older fauna co-existed with the basal clades of the more recent insect fauna (Carpenter and Burnham, 1985). Relevant herbivorous lineages of the old fauna were paleodictyopteroids, orthopteroids, and basal hemipteroids; the new fauna consisted of derived orthopteroids and hemipteroids, and especially newly emerging holometabolans (Labandeira, 2005; Haug et al., 2015). The clades in the new fauna, which later give rise to the Modern Insect Fauna, preferentially survived the P-Tr event (Labandeira and Sepkoski, 1993; Jarzembowski and Ross, 1996).

One way to assess the Permian pattern of lineage turnover is by examination of the dominant insect faunas during the formative early Permian (Cisuralian), when overlap probably was maximal between the older Paleozoic Insect Fauna, dominant during the Pennsylvanian, and the newer Modern Insect Fauna that predominated during the Mesozoic and Cenozoic (Labandeira, 2005). The principal Cisuralian insect macrofaunas are Elmo, in Kansas, U.S.A., of Artinskian age at ca. $281 \mathrm{Ma}$ (Beckemeyer, 2000) and Chekarda, in Uralian Russia, at ca. $275 \mathrm{Ma}$ (Novokshonov, 1998; Shcherbakov, 2008). However, these two most diverse insect faunas of the Cisuralian are uninformative for understanding the ecology of early Permian insects, particularly the life habits of herbivorous taxa and their relationships to plant hosts. A complementary approach, given the general rarity of early Permian insect occurrences, is to search for insectmediated damage on early Permian floras.

Three early Permian floras from north-central Texas have previously been analyzed qualitatively and quantitatively for insect herbivory. Their stratigraphic positions are known, with 
the lowest being Coprolite Bone Bed (CBB; Labandeira and Allen, 2007), followed by Taint (Beck and Labandeira, 1998), and Colwell Creek Pond (CCP; Schachat et al., 2014). However, correlation of these beds with the global time scale at this time is problematic. These deposits are Cisuralian in age. Previously reported stages and numerical ages for these floras reported by Labandeira and Allen (2007), Beck and Labandeira (1998), and Schachat et al. (2014) are inconsistent with the current stage and numerical date alignments proposed in the International Chronostratigraphic Chart of the International Commission on Stratigraphy in October of 2014 (Cohen et al., 2013; updated). Nevertheless, a mid Cisuralian assignment of these floras currently is supportable. The present study of insect damage from Mitchell Creek Flats (MCF) represents the fourth locality examined to date from the Cisuralian of Texas. MCF is older than CCP and provides a separate analysis that includes evaluations of the abundance and richness of herbivory as well as quantitative measures of herbivorized surface area. Cumulatively, these four floras provide evidence for the unique insect feeding patterns and likely insect behavioral evolution that occurred during the earlier Permian.

These floras represent a variety of habitats and comprise one of four sets of assemblages from the early to middle Permian for which plant-insect interactions are being examined. The other assemblages are a series of Gondwanan floras from the Karoo Basin in South Africa (Prevec et al., 2009; Labandeira and Prevec, 2014), the Paraná Basin of southeastern Brazil (AdamiRodrigues et al., 2004; Pinheiro, 2012), and the Miohuda, Raniganj, and temporally related basins of India (Srivastava, 1987; Banerjee and Bera, 1998). Modern latitudinal patterns of insect herbivore diversity (Adams and Zhang, 2009) suggest that the north-central Texas floras, which were deposited considerably closer to the Permian paleoequator than those of the Gondwanan assemblages, probably contain a greater diversity of plant hosts and insect herbivores. However, the strength of taxonomic diversity gradients in deep time, particularly those dating back to the Paleozoic, still remains unclear (Crame, 2001). 
The redbed sequence of north-central Texas provides a unique window into the early ecological aspects of the Paleozoic to Modern insect faunal transition. Floristically, Pennsylvanian-age coal swamps were replaced by seasonally dry biotas during the Early Permian (DiMichele et al., 2009; DiMichele et al., 2011; Tabor et al., 2013). Faunistic turnover occurred far more gradually: the lingering Paleozoic Insect Fauna, affiliated with the older coal-swamp biotas, was slowly replaced by early representatives of the Modern Insect Fauna, associated with more xeric habitats (Labandeira, 2006a, 2006b). These deposits provide the basic data for understanding the changes of the physical environment, the evolution of the herbivorous insect fauna, and the latter's interactions with plants during the early Permian. The environmental context includes increasingly dry climates (DiMichele et al., 2005) and glacial-interglacial cycles (DiMichele et al., 2010; Montañez and Poulsen, 2013) that, in turn, likely affected floral change and development of the vegetational habitat mosaic (cf. Thompson, 2013) that existed in Texas at this time (Tabor et al., 2008). MCF provides another opportunity to quantify the variability of insect herbivory within this critical interval.

\section{Geologic and biologic setting}

Much of the geologic and biologic context of the MCF locality is given in Chaney et al. (2005). The MCF locality is one of dozens occurring in the redbed sequence of the north-central Texas early Permian (Cisuralian) that forms the primary documentation for understanding biotic evolution in this region (DiMichele et al., 2005, 2010).

\subsection{Geologic context of Mitchell Creek Flats}

The MCF locality is in northeastern Baylor County, Texas, and includes three locality numbers that indicate separate collecting events at the same locality: USNM localities 40049, 40999, and 41661 (Fig. 1). This locality is in the uppermost Waggoner Ranch Formation, about 10 meters below its contact with the Lueders Formation (Fig. 1). In general, the locality occurs in 
the area known as the "flats," which covers ca. 4000 square meters. The claystone sediment at the site was deposited within a shallow channel-like depression less than $3 \mathrm{~m}$ deep. A 3-5 cm layer of pedogenic carbonate gravel forms the base of the channel fill. Narrow, long plant axes with hollowed, central piths surrounded by indurated tissue, lie on top of the basal conglomerate. These relatively insubstantial, nonwoody plant axes are aligned in an east-west direction and likely were emplaced by currents before accumulating at the northern edge of the river channel (also see Chaney et al., 2005). All plant and animal fossils at Mitchell Creek Flats were recovered from a 55-cm-thick gray clay bed. The bed is composed of fine, uniform, clay-sized grains and displays no evidence of bioturbation, suggesting that the fossils were deposited in a quiescent, standing body of water. Above this layer is a red and yellow paleosol developed in a $25 \mathrm{~cm}$-thick layer of clay and siltstone. The deposit is capped by $25 \mathrm{~cm}$ of sandstone. An early Permian or Cisuralian age of these strata is supported by the vertebrate material found in this formation as well as the interfingering of MCF and subjacent and superjacent beds with early Permian marine strata to the south (Hentz, 1988). 


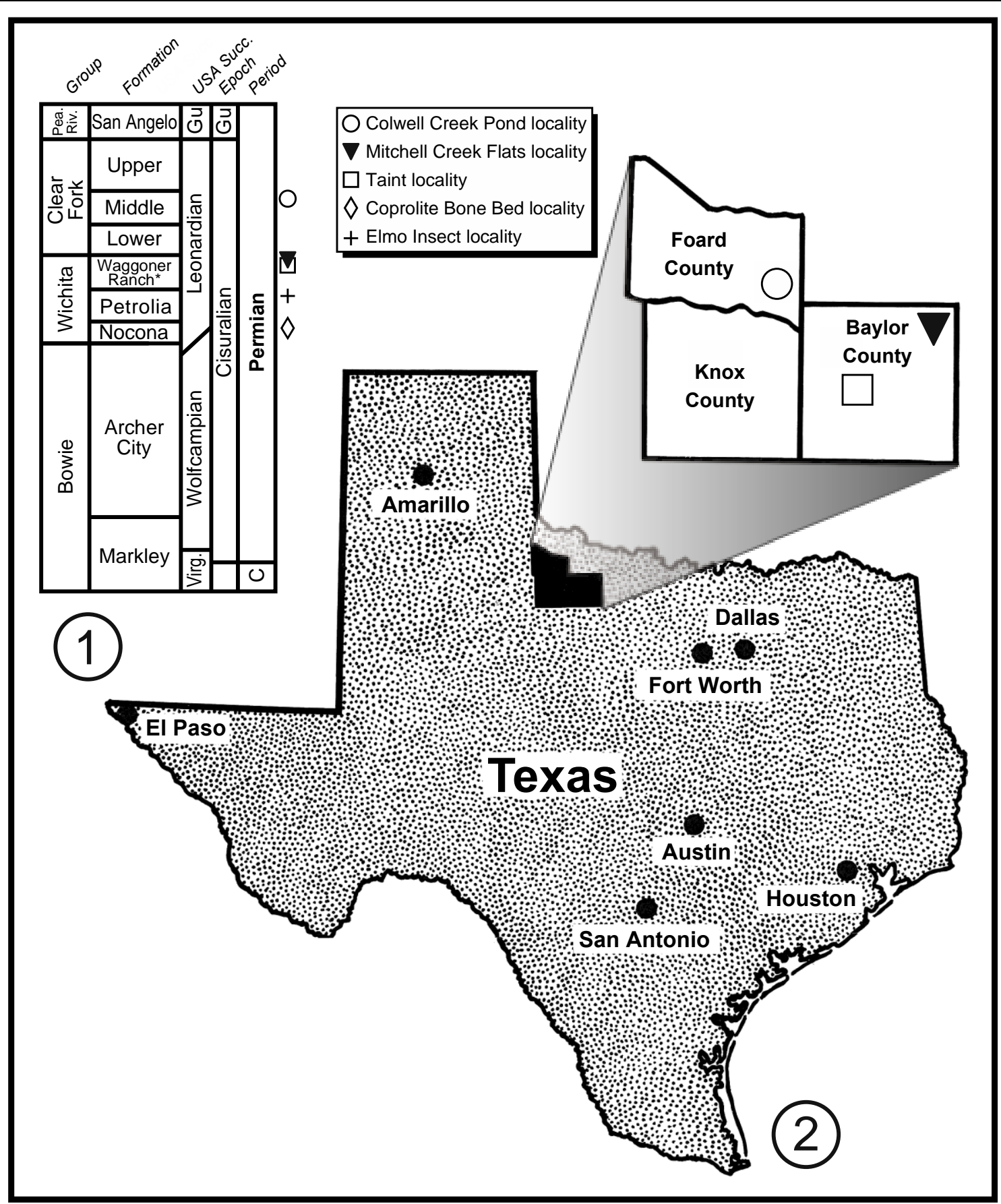

Fig. 1. Geographic and stratigraphic setting of the Mitchell Creek Flats (MCF) locality from the early Permian (Cisuralian) of north-central Texas, showing the regional lithostratigraphy and stage-level assignments, and global stage, epoch, and period equivalents. The stratigraphic and geographic positions of the MCF flora and other previously examined floras are indicated by 
symbols. Formation designations largely are from Hentz (1988), and global successions are based on Gradstein et al. (2012). For additional details regarding the MCF flora, see Chaney et al. (2005). Abbreviations; C, Carboniferous; Gu, Guadalupian; Pea. Riv., Pease River Group; Ro, Roadian; Succ., succession; Virg., Virgilian. In the column listing the Waggoner Ranch Formation, an asterisk indicates the uppermost unit, the Lueders Formation (not indicated), which lies about $10 \mathrm{~m}$ above the MCF flora. This figure is modified from Schachat et al. (2014).

The surrounding seasonally-dry flora was of low diversity and contained a mixture of shrubs, vines, and herbaceous elements. The MCF local fauna includes a xenacanthid shark, paleonisciform fish, and a diplocaulid nectridian (Diplocaulus), members of a freshwater pond community that also included numerous conchostracans (Pseudestheria) and myalinid clams (Chaney et al., 2005). The local plant community was dominated by seed plants, contained a few sphenopsids, but lacked lycopsids and ferns.

\subsection{Comparison of Mitchell Creek Flats with other spatiotemporally related Texas localities}

The MCF flora originates from a fluvially dominated deposit from the early Permian of north-central Texas. All the localities examined from north-central Texas were deposited on the eastern coastal shelf of the Permian Basin. The oldest locality, Coprolite Bone Bed (CBB) was deposited in an actively infilling channel and has a diversity of 12 plant taxa ranked at various taxonomic levels. The locality is represented by 598 total specimens and is dominated by peltasperms with subdominant conifers and cordaites. The younger Taint locality was deposited in a somewhat different riparian setting, is dominated by gigantopterids and subordinately by peltasperms, consists of 14 plant taxa ranked at multiple taxonomic levels, and is represented by 1346 specimens. The current MCF locality was deposited in a pond within an abandoned stream channel and is represented by 820 specimens belonging to 23 plant taxa (Table 1), dominated by cycadophytes with subdominant gigantopterids. The youngest locality, CCP, is from a clay filled 
oxbow pond, consisting of dominant peltasperms with subdominant conifers and cycadophytes, contains 12 major taxa, and is represented by 2140 specimens. With their unique patterns of plant dominance, each of these four floras provides a unique combination of host plants accessible to insect herbivores. 
Table 1. Original and herbivorized surface area and percentage removal for the early Permian (Cisuralian) Mitchell Creek Flats locality (bulk floral data) from Texas.

\begin{tabular}{|c|c|c|c|c|c|c|c|c|c|}
\hline $\begin{array}{l}\text { Foliar taxon (abundance } \\
\text { ranked) }\end{array}$ & $\begin{array}{c}\text { Number } \\
\text { of } \\
\text { specimens }\end{array}$ & $\begin{array}{c}\text { Specimens } \\
\text { examined } \\
\text { of total } \\
\text { number } \\
(\%)\end{array}$ & $\begin{array}{l}\text { Surface area } \\
\text { examined of } \\
\text { total number } \\
\quad(\%)\end{array}$ & $\begin{array}{c}\text { Total } \\
\text { surface } \\
\text { area }\left(\mathrm{cm}^{2}\right)\end{array}$ & $\begin{array}{l}\text { Herbivorized } \\
\text { surface area } \\
\quad\left(\mathrm{cm}^{2}\right)\end{array}$ & $\begin{array}{l}\text { Proportion of } \\
\text { total } \\
\text { herbivorized } \\
\text { specimens } \\
(\%)\end{array}$ & $\begin{array}{l}\text { Herbivory } \\
\text { index }(\%)\end{array}$ & $\begin{array}{l}\text { Number of } \\
\text { herbivorized } \\
\text { specimens }\end{array}$ & $\begin{array}{l}\text { Proportion } \\
\text { of } \\
\text { herbivorized } \\
\text { specimens } \\
(\%)\end{array}$ \\
\hline Seed type $1^{1}$ & 409 & 49.88 & 2.05 & 40.45 & 0.01 & 0.02 & 0.02 & 1 & 2.04 \\
\hline Seed type $2^{2}$ & 190 & 23.17 & 7.19 & 141.99 & 0.13 & 0.41 & 0.09 & 6 & 12.24 \\
\hline Taeniopteris sp. & 104 & 12.68 & 60.64 & 1197.44 & 31.82 & 96.83 & 2.66 & 26 & 53.06 \\
\hline Zeilleropteris sp. & 20 & 2.44 & 8.51 & 167.99 & 0.61 & 1.85 & 0.36 & 9 & 18.37 \\
\hline Indeterminate axis & 18 & 2.2 & 4.99 & 98.63 & 0 & 0 & 0 & 0 & 0 \\
\hline ?Brachyphyllum sp. & 14 & 1.71 & 0.82 & 16.21 & 0 & 0 & 0 & 0 & 0 \\
\hline Indeterminate broadleaf & 14 & 1.71 & 0.9 & 17.78 & 0.02 & 0.06 & 0.11 & 1 & 2.04 \\
\hline ?Rhachiphyllum sp. & 12 & 1.46 & 1.88 & 37.05 & 0 & 0 & 0 & 0 & 0 \\
\hline Cathaysiopteris sp. & 9 & 1.1 & 1.95 & 38.56 & 0.2 & 0.59 & 0.51 & 2 & 4.08 \\
\hline cf. Cathaysiopteris & 8 & 0.98 & 1.34 & 26.51 & 0 & 0 & 0 & 0 & 0 \\
\hline $\begin{array}{l}\text { Indeterminate } \\
\text { fructification }^{3}\end{array}$ & 6 & 0.73 & 1.12 & 22.1 & 0 & 0 & 0 & 0 & 0 \\
\hline Pteridosperm foliage type 1 & 3 & 0.37 & 5.57 & 109.96 & 0.01 & 0.03 & 0.01 & 1 & 2.04 \\
\hline cf. Comia sp. & 2 & 0.24 & 0.36 & 7.2 & 0.02 & 0.05 & 0.24 & 1 & 2.04 \\
\hline cf. Odontopteris sp. & 2 & 0.24 & 0.49 & 9.73 & 0 & 0 & 0 & 0 & 0 \\
\hline Annularia sp. & 1 & 0.12 & 0.33 & 6.51 & 0 & 0 & 0 & 0 & 0 \\
\hline Calamites sp. & 1 & 0.12 & 0.11 & 2.16 & 0 & 0 & 0 & 0 & 0 \\
\hline cf. Zeilleropteris & 1 & 0.12 & 0.52 & 10.3 & 0.04 & 0.12 & 0.38 & 1 & 2.04 \\
\hline
\end{tabular}




\begin{tabular}{|l|c|c|c|c|c|c|c|c|c|} 
Gigantonoclea sp. & 1 & 0.12 & 0.05 & 0.89 & 0 & 0 & 0 & 0 \\
\hline Euparyphoselis sp. & 1 & 0.12 & 0.67 & 13.32 & 0 & 0 & 0 & 0 & 0 \\
\hline Indeterminate callipterid & 1 & 0.12 & 0.16 & 3.1 & 0 & 0 & 0 & 0 \\
\hline Pteridosperm foliage type 2 & 1 & 0.12 & 0.23 & 4.5 & 0.01 & 0.04 & 0.29 & 1 & 2.04 \\
\hline Phasmatocycas sp. & 1 & 0.12 & 0.08 & 1.61 & 0 & 0 & 0 & 0 & 0 \\
\hline ?Sandrewia sp. & 1 & 0.12 & 0.03 & 0.56 & 0 & 0 & 0 & 0 & 0 \\
\hline Totals/percent sums & 820 & 100 & 100 & 1974.54 & 32.86 & 100.01 & 0.2 & 49 & 100 \\
\hline
\end{tabular}

${ }^{1}$ A small, unwinged seed.

${ }^{2}$ A rather large, samaropsoid, winged seed

${ }^{3}$ Includes possible Noeggeranthialean strobili. 


\section{Materials and Methods}

Our study of MCF plant-insect interactions employs three approaches that variously measure the intensity and richness of herbivory at MCF. The first procedure was a qualitative examination of the foliar and associated plant material for evidence of herbivory. The second procedure was a quantitative analysis of herbivory based on assessments of the frequency of attack and damage richness. In the third procedure, we measured the percentage of leaf-surface area removed by herbivores. The three procedures were carried out for all plant taxa in the flora. The methods described below parallel those used in previous studies of fossil and modern floras (Beck and Labandeira, 1998; Adami-Rodrigues et al., 2004; Labandeira and Allen, 2007; Adams and Zhang, 2009; Schachat et al., 2014). Although Taeniopteris spp., the most abundant type of foliage at $\mathrm{MCF}$, is known to be a polyphyletic form genus, we treat it here as a cycadophyte, as Taeniopteris leaves with sori are rare at CCP and absent at the other three studied Texas fossil localities. There appear to be at least two forms of Taeniopteris at MCF, and possibly others. Thus throughout this paper we refer to this form genus as representing more than one natural taxon, using "spp." An effort is currently under way to distinguish and define these natural taxa but it is presently too early to establish the species-level divisions of Taeniopteris. All analyzed specimens are housed in the USNM Paleobotany Collections, at the National Museum of Natural History, Smithsonian Institution, in Washington, D.C.

\subsection{Qualitative analysis}

The recognition of herbivory at MCF was based on several established criteria (Labandeira, 1998; Scott and Titchener, 1999; Labandeira et al., 2002) that have been employed in previous studies but seldom explicitly stated in other examinations of herbivory. Due to the Paleozoic age of the MCF flora, no attribution to extant herbivorous taxa is possible, as has been done for angiosperm-dominated floras from the mid Cretaceous to Recent (e.g., Opler, 1973; Waggoner and Poteet, 1996; Wilf et al., 2000). The absence of taxonomic uniformitarianism at MCF 
necessitated the use of intrinsic attributes of insect-mediated patterns of plant damage that would be independent of time, place, plant host, or insect herbivore lineage. These attributes rely on universal functional principles pertaining to the structure, behavior, and ecology of a variety of insect feeding patterns on modern vegetation (Gangwere, 1966; Ruth, 1980; Kazakova, 1985; Meyer, 1987; Labandeira, 2002). Most important are distinctive insect modifications of plant tissues during feeding that involve mandibulate external feeders (Boys, 1989; Chapman and Joern, 1990), piercers and suckers (Weber, 1930; Dixon and Thieme, 2007), ovipositing insects (Carpenter, 1971; Hellmund and Hellmund, 1996), gallers (Goidianich, 1960; Meyer, 1987), seed predators (Ruth, 1980), and occasionally the responses of host plants to rarer types of damage, such as fungal necrotization (Sinclair et al., 1987; Tovar et al., 1995).

There are four kinds of foliar morphological features that indicate consumption of live tissue. First is the presence of thick, upraised rims of reaction tissue, particularly parenchyma-derived callus that is produced by the host plant and occurs on live tissues that have been damaged by insect herbivores (Meyer, 1987; Johnson and Lyon, 1991). Second are atypical histological features associated with the external or internal consumption of foliage or other live plant organs. Examples on leaves include necrotized tissue flaps or veinal stringers left by insects that are unable to completely ingest physically resistant epidermal cuticles and vascular tissue (Keen, 1952; Weintraub et al., 1994; Araya et al., 2000). Another instance is the presence of contiguous cuspules formed along a cut leaf margin within larger cuspate excisions that can reveal the trajectory of insect head movement and mouthpart action during feeding (Gangwere, 1966; Kazakova, 1985). A third line of evidence is the repeated stereotypy of tissue removal modes based on shape, size, and juxtaposition of damage within the affected plant organ, such as vein avoidance and the occurrence of distinctive patterns of herbivory at particular leaf regions (Bodnaryk, 1992; Heron, 2003). Last is the preferential presence of plant damage on particular host-plant tissues, organs, and species, indicating herbivore targeting rather than the more random distributions that would be expected from physical breakage by wind or water (MacKerron, 1976; 
Wilson, 1980; Vincent, 1990), and from the nonspecific tissue preferences of detritivores once the plant tissue is dead (Brues, 1924; Mitter et al., 1988).

All seeds were examined, regardless of size. All other plant material with a surface area of $0.5 \mathrm{~cm}^{2}$ or larger was examined. Parts and counterparts were matched whenever possible to avoid duplication. After the initial differentiation of herbivory from physical battering and detritivory, the spectrum of insect-mediated damage at MCF was categorized into five major FFGs, or primary insect-feeding modes. Within each FFG, each particular kind of insect damage was categorized using a system of explicitly defined DTs (Wilf and Labandeira, 1999; Labandeira et al., 2002; Labandeira, 2006a; Labandeira et al., 2007). We did not assess fungal damage explicitly in the analysis, but occasional fungal damage (Hammon and Faeth, 1992) was associated with particular interactions, such as necrotic tissue surrounding certain external foliage feeding damage, and was recorded.

\subsection{Quantitative analyses}

Two types of quantitative assessments, used in modern studies, were applied in characterizing MCF herbivory. First was the determination of the proportion of the flora that displayed an indication of herbivory, expressed as a percentage of herbivorized specimens as a fraction of the total number of examined foliar specimens (Schmidt and Zotz, 2000). Second was the herbivory index, which expresses the percentage of the herbivorized surface area as a fraction of the total (unherbivorized + herbivorized) surface area (Landsberg, 1989; Williams and Abbott, 1991). Each specimen was initially digitized under appropriate lighting conditions using a Canon EOS 50D camera with a Canon EF-S $60 \mathrm{~mm} \mathrm{f/2.8} \mathrm{macro} \mathrm{lens.} \mathrm{After} \mathrm{image} \mathrm{capture,} \mathrm{each} \mathrm{foliar} \mathrm{element}$ and its insect-damaged zones, if any, were digitized using Adobe Photoshop Elements 10. A conservative approach was taken, as in previous studies (Beck and Labandeira, 1998; Labandeira and Allen, 2007; Schachat et al., 2014), whereby foliar element silhouettes were justified anatomically or estimated based on previous knowledge of leaf-shape outlines and morphological 
variability (Adami-Rodrigues et al., 2004, Fig. 4.3; Schachat et al., 2014). Areas encompassed by total foliar and insect-herbivorized outlines were calculated in Media Cybernetics Image Pro Plus. These data subsequently were entered into an Excel 2011 spreadsheet. Excel and $R$ version 3.1.2 (R Development Core Team, 2013) were used for later statistical analysis. All indices were expressed as values for each measured host-plant species as well as for the bulk flora. (See Mazia et al., [2004] for a modern example.)

\subsection{Photodocumentation}

For more detailed image capture of insect herbivory damage on foliar surfaces, specimens were photographed under high magnification using an Olympus SZX12 microscope attached to an Olympus DP25 camera. Low-angle light originated from a Dolan-Jenner Fiber-Lite MI-150 high intensity illuminator for microtopographic documentation of damaged areas. Images were white-balanced, focused, and captured using Olympus DP2-BSW imaging software.

\subsection{Comparisons across Localities}

We compared patterns of herbivory at the four sites from north-central Texas using two approaches. Because seeds, axes, conifer needles, and broadleaf foliar material are present in different proportions at the four sites and are herbivorized by different insect guilds (Strong et al., 1984), we controlled for the potential confounding variable of organ type by limiting our analysis to broadleaf foliage. The indeterminate broadleaf categories at Taint (Indeterminate broadleaf) and MCF (Indeterminate broadleaf, Pteridosperm foliage type 1, Pteridosperm foliage type 2, and Indeterminate callipterid) were retained because these categories contain plants that, although subject to taxonomic uncertainty, are believed to represent single, monophyletic taxa. The indeterminate broadleaf category from $\mathrm{CCP}$ was excluded because this category represents a collection of multiple plant taxa from various lineages that were too poorly preserved to be identified with any level of certainty. Taeniopteris spp. from MCF and CCP was retained, despite the possible polyphyletic nature of this form genus, for two reasons. First, it represents a large 
component of the CCP flora (47.51\% of broadleaf specimens and $28.13 \%$ of broadleaf surface area). Second, the morphological variability of specimens placed into the genus, while not known, can be valuable in future studies that may associate certain phenotypic variants of a taxon such as Taeniopteris with particular types of insect herbivory.

First, we employed ordination methods to visualize the relationship between locality and foliar taxon with respect to FFGs. More broadly defined FFGs, instead of DTs, were analyzed by necessity because DT data are not available for Taint. This same approach - using FFGs - has been taken in other studies for which both types of data were available, for the purpose of increasing the signal to noise ratio (Currano et al., 2010). A Bray-Curtis dissimilarity matrix was computed and used in a nonmetric multidimensional scaling ordination with the "metaMDS" function of the vegan package, version 2.0-10 (Oksanen et al, 2013) in $R$. Second, we visualized the relationship between the relative abundance, or apparency, of a taxon (Feeny, 1976), and the frequency and severity of insect attack. We generated graphical representations of insect herbivory at the four localities from north-central Texas, also using $R$.

\section{Results}

\subsection{Overall patterns of floral composition and herbivory}

The MCF flora at the USNM collections is represented by 820 specimens representing 23 identifiable formal and informal taxa that include seven major groups: sphenopsids, pteridosperms, a conifer, a noeggeranthialean, cycads, gigantopterids, and peltasperms (Table 1). The most abundant elements were the unidentifiable seeds that collectively constituted $73.05 \%$ of the specimens examined but could not be attributed to co-occurring seed-plant taxa or to known elements from other Euramerican Cisuralian floras. Seed type 1 (exemplified by USNM 612210, Fig. 6.1) constitutes half of all specimens, is small, lenticular in shape, and either possessed miniscule wings or lacked wings altogether. Seed type 2 (exemplified by USNM 612226, Fig. 
6.2) constitutes somewhat less than one-fourth of all specimens and is a large samaropsid seed with prominent wings. Indeterminate axes constitute one-sixth of the flora.

Of the seven identifiable botanical taxa, the most abundant seed plants are the probable cycadophytes in the form-genus Taeniopteris spp. (104 specimens). The leaf structure of Taeniopteris spp. (exemplified by USNM 612215, Fig. 3.1) suggests attribution to a cycadophyte, also supported by presence of the cycadophyte fructification Phasmatocycas (1 specimen: USNM 528172). The second most abundant group were gigantopterids (40 specimens), represented by three genera: Zeilleropteris sp. (exemplified by USNM 612217, Fig. 5.1), Cathaysiopteris sp. (exemplified by USNM 612221, Fig. 5.5), and an indeterminate genus designated as cf. Cathaysiopteris (exemplified by USNM 528166). A specimen (USNM 528159) originally misidentified as Delnortea (Chaney et al., 2005); whose taxonomic affiliation is under study; is herein designated cf. Zeilleropteris (pers. comm. Rebecca Koll 6/30/2015), The third most abundant group were pteridosperms, evidenced by four genera (20 specimens) that were mostly indeterminate at lower taxonomic levels, but consisted of four taxa referable to Indeterminate broadleaf (exemplified by USNM 616675), Pteridosperm foliage type 1 (exemplified by USNM 528186), cf. Odontopteris (exemplified by USNM 616668), and Pteridosperm foliage type 2 (exemplified by USNM 528160). Peltasperms were the fourth most abundant group (16 specimens) containing, with some taxonomic uncertainties, the four foliage taxa of ?Rhachiphyllum (possibly affiliated with Autunia; exemplified by USNM 528180), cf. Comia (exemplified by USNM 616672), Indeterminate callipterid (exemplified by USNM 616669), and the fructification ?Sandrewia (exemplified by USNM 616670). The fifth most abundant group consisted of 14 specimens of a conifer likely affiliated with ?Brachyphyllum (exemplified by USNM 528181). Sixth in order of abundance were noeggerathialean strobili represented by six specimens (exemplified by USNM 528162). Least abundant, each represented by a single specimen, were two taxa belonging to the only non-seed plant groups present: the fern Annularia sp. (exemplified by USNM 528170) and the horsetail Calamites sp. (exemplified by USNM 
528176). Even though the unidentifiable seeds accounted for $73 \%$ of the specimens in the flora, the two most abundant foliage genera - Taeniopteris spp. and Zeilleropteris sp. - account for $69.2 \%$ of the total plant surface area (Table 1).

The total plant surface area examined was $1974.54 \mathrm{~cm}^{2}$. (This represents a square of exposed plant tissue that is $44.45 \mathrm{~cm}$. on a side.) The maximum surface area of any single leaf was 101.76

$\mathrm{cm}^{2}$. Seeds and seed fragments had small surface areas, ranging from 0.01 to $2.71 \mathrm{~cm}^{2}$. Forty-nine (5.98\%) of specimens examined exhibited signs of insect-mediated herbivory (Table 1). There were 59 instances of herbivory observed overall: 52 on broadleaved material and seven on seeds. Some specimens showed the presence of two functional feeding groups, and one specimen exhibited three DTs, one each from margin feeding, piercing and sucking, and galling.

\subsection{Types of damage}

There are 22 Damage Types (DTs) recorded from the MCF deposit, which are categorized into the five FFGs of: (i) external foliage feeding, subdivided into margin feeding, surface feeding, and hole feeding; (ii) piercing and sucking; (iii) oviposition; (iv) galling; and (v) seed predation. We have considered oviposition, an egg-laying process, as a FFG since it involves significant modification of plant tissue, such as formation of lesions, scarring, and the loss of photosynthetic surface area. Oviposition has a good fossil record and parallels the four types of true feeding at MCF and other early Permian sites from north-central Texas. The greatest diversity of herbivory by host plant occurs on Taeniopteris spp. (Table 2), which overwhelmingly is the most abundant broadleaf taxon at the site (57.8\% of specimens). Taeniopteris spp. exhibited $45.83 \%(11 / 24)$ of the total occurrences of external foliage feeding, $75 \%(3 / 4)$ of the piercing and sucking, $83.33 \%$ (5/6) of the oviposition, and $82.35 \%$ (14/17) of the galling, including two of the three new gall DTs at MCF. 
Table 2. Incidences of DTs by Functional Feeding Group for each herbivorized plant host at the early Permian (Cisuralian) Mitchell Creek Flats flora.

\begin{tabular}{|c|c|c|c|c|c|c|c|c|c|c|c|c|c|c|c|c|c|c|c|c|c|c|c|}
\hline \multirow[b]{4}{*}{$\begin{array}{l}\text { Damage } \\
\text { Type }\end{array}$} & \multicolumn{22}{|c|}{ Functional Feeding Groups and Damage Types (DTs) } & \multirow{4}{*}{$\begin{array}{l}\mathbf{T} \\
\mathbf{O} \\
\mathbf{T} \\
\mathbf{A} \\
\mathbf{L} \\
\mathbf{S}\end{array}$} \\
\hline & \multicolumn{7}{|c|}{ External Foliage Feeding } & \multirow{2}{*}{\multicolumn{2}{|c|}{$\begin{array}{l}\text { Piercing } \\
\text { and } \\
\text { Sucking }\end{array}$}} & & \multirow{2}{*}{\multicolumn{3}{|c|}{ Oviposition }} & \multirow{2}{*}{\multicolumn{6}{|c|}{ Galling }} & \multirow{2}{*}{\multicolumn{3}{|c|}{ Seed Predation }} & \\
\hline & $\begin{array}{l}\text { Hole } \\
\text { Feed } \\
\text {-ing }\end{array}$ & \multicolumn{3}{|c|}{$\begin{array}{l}\text { Margin } \\
\text { Feeding }\end{array}$} & \multicolumn{3}{|c|}{$\begin{array}{l}\text { Surface } \\
\text { Feeding }\end{array}$} & & & & & & & & & & & & & & & & \\
\hline & DT2 & $\begin{array}{l}\text { DT } \\
12\end{array}$ & $\begin{array}{l}\text { DT } \\
13\end{array}$ & $\begin{array}{l}\text { DT } \\
143\end{array}$ & $\begin{array}{l}\text { DT } \\
29\end{array}$ & $\begin{array}{l}\text { DT } \\
30\end{array}$ & $\begin{array}{l}\text { DT } \\
31\end{array}$ & $\begin{array}{l}\text { DT } \\
46\end{array}$ & $\begin{array}{l}\text { DT } \\
48\end{array}$ & $\begin{array}{l}\text { D1 } \\
76\end{array}$ & $\begin{array}{l}\text { DT } \\
100\end{array}$ & $\begin{array}{l}\text { DT } \\
101\end{array}$ & $\begin{array}{l}\text { DT } \\
246\end{array}$ & $\begin{array}{l}\text { DT } \\
32\end{array}$ & $\begin{array}{l}\text { DT } \\
80\end{array}$ & $\begin{array}{l}\text { DT } \\
247\end{array}$ & $\begin{array}{l}\text { DT } \\
265\end{array}$ & $\begin{array}{l}\text { DT } \\
266\end{array}$ & $\begin{array}{l}\text { DT } \\
267\end{array}$ & $\begin{array}{l}\text { DT } \\
73\end{array}$ & $\begin{array}{l}\text { DT } \\
74\end{array}$ & $\begin{array}{l}\text { DT } \\
124\end{array}$ & \\
\hline $\begin{array}{l}\text { Taeniopteris } \\
\text { sp. }\end{array}$ & 1 & 7 & 1 & 1 & & & 1 & 1 & 2 & 2 & 1 & 1 & 1 & 2 & 4 & 1 & 1 & 6 & & & & & 33 \\
\hline $\begin{array}{l}\text { Zeilleropteris } \\
\text { sp. }\end{array}$ & 4 & 1 & & 1 & 1 & & & 1 & & & & & & & 1 & & & & 1 & & & & 10 \\
\hline $\begin{array}{l}\text { Cathaysio- } \\
\text { pteris sp. }\end{array}$ & & & & & & 1 & 1 & & & & & 1 & & & & & & & & & & & 3 \\
\hline $\begin{array}{l}\text { Pteridosperm } \\
\text { foliage type } 1\end{array}$ & & 1 & & & & & & & & & & & & & & & & & & & & & 1 \\
\hline cf. Comia & 1 & & & & & & & & & & & & & & & & & & & & & & 1 \\
\hline $\begin{array}{l}\text { Pteridosperm } \\
\text { foliage type } 2\end{array}$ & & 1 & & & & & & & & & & & & & & & & & & & & & 1 \\
\hline $\begin{array}{l}\text { cf. } \\
\text { Zeilleropteris }\end{array}$ & 1 & & & & & & & & & & & & & & & & & & & & & & 1 \\
\hline $\begin{array}{l}\text { Indeterminate } \\
\text { broadleaf }\end{array}$ & & & & & & & & & & & & & & & 1 & & & & & & & & 1 \\
\hline $\begin{array}{l}\text { Seed } \\
\text { type } 2^{1}\end{array}$ & & & & & & & & & & & & & & & & & & & & 1 & 4 & 1 & 6 \\
\hline $\begin{array}{l}\text { Seed } \\
\text { type } 1^{2}\end{array}$ & & & & & & & & & & & & & & & & & & & & & 1 & & 1 \\
\hline DT Totals & 7 & 10 & 1 & 2 & 1 & 1 & 2 & 2 & 2 & 2 & 1 & 2 & 1 & 2 & 6 & 1 & 1 & 6 & 1 & 1 & 5 & 1 & 58 \\
\hline FFG Totals & 7 & & 13 & & & 4 & & & & & & 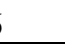 & & & & & 7 & & & & 7 & & 50 \\
\hline
\end{tabular}

${ }^{1}$ Winged samaropsid seed.

${ }^{2}$ Small unwinged seed. 
The broad spectrum of herbivory at MCF is similar to that of the three other sites from northcentral Texas (Fig. 2). No evidence of skeletonization, wood boring or leaf mining was found at MCF. Skeletonization, the consumption of the entire thickness of a leaf in which one or more ranks of venation is left unconsumed, is rarely encountered in Pennsylvanian and Permian floras (Feng et al. 2014). Wood boring requires the preservation of three-dimensional tunnels or galleries in woody or otherwise indurated tissues and seldom occurs in late Paleozoic adpression floras (Shute and Cleal, 1987), although there are examples where permineralizations occur with preservation of broadleaf floras (Rößler and Fiedler, 1996; Naugolnykh and Ponomarenko, 2010, but see Schachat et al. 2014). The earliest documented occurrences of leaf mining are from Middle and Late Triassic deposits of South Africa and Eurasia (Labandeira, 2006a, 2006b; Wappler et al., 2015).

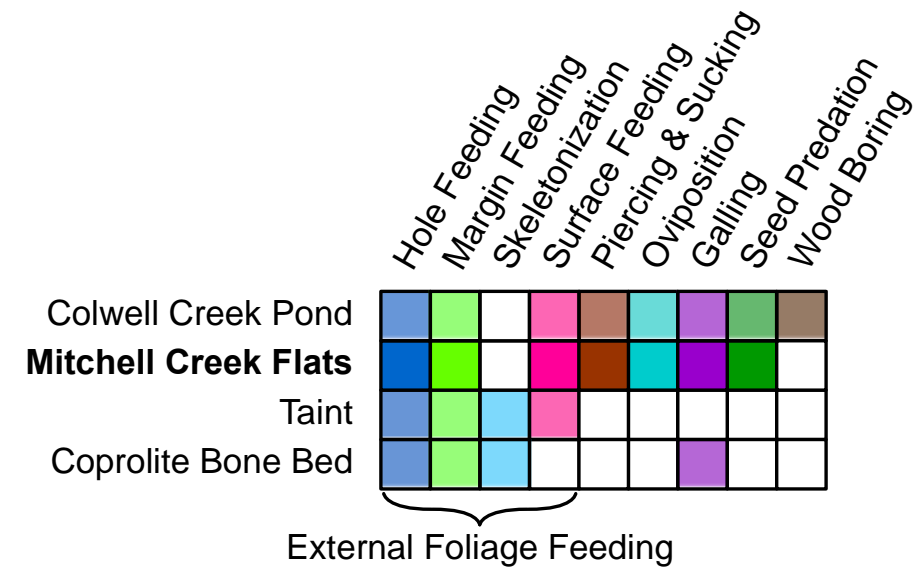

Fig. 2. Functional Feeding Group (FFG) occurrences in Permian floras from north-central Texas. Colored squares indicate presence of a FFG; white squares indicate absence. The colors used here correspond to those used in the Guide to Insect (and Other) Damage Types on Compressed Plant Fossils (Labandeira et al., 2007). 
Fig. 3. Margin feeding (1-11), piercing-and-sucking (12-13), oviposition (14-20), and galling (18-20) on Taeniopteris spp. DT13 is at 1 (USNM 612215), enlarged at 2. DT12 is at 3 (USNM 612223), enlarged at 4 and 5. DT143 is at 6 (USNM 612212), with veinal stringers enlarged at 7 and 8. A particularly large DT12 margin feeding is at 9 (USNM 612206), enlarged at 10, with veinal stringers visible at 11. Piercing-and-sucking occurs at 12 (USNM 612210), enlarged at 13. DT100 is figured at 14 (USNM 612220), enlarged at 15-17. Singularly occurring oviposition scars (DT76 and DT101) and small galls (DT266) are shown in 18 (USNM 612213), with DT76 enlarged at 19 and DT101 enlarged at 20. Scale bars: solid black, $10 \mathrm{~mm}$; solid white, $1.0 \mathrm{~mm}$; dashed, $0.1 \mathrm{~mm}$.

Fig. 4. Galling (1-14), margin feeding (9), and oviposition $(13,15)$ on Taeniopteris spp. A new Damage Type, DT265, is at 1 (USNM 612207), enlarged at 2, 3, and 4. Another new damage type, DT266, is at 5 (USNM 612211), enlarged at 6, 7, and 8. DT12 and DT80 are at 9 (USNM 612209), with DT80 enlarged at 10. DT32 is at 11 (USNM 612208), enlarged at 12. DT246 and DT247 are at 13 (USNM 612225), with DT246 enlarged at 14 and DT247 enlarged at 15. Scale bars: solid black, $10 \mathrm{~mm}$; solid white, $1.0 \mathrm{~mm}$; dashed, $0.1 \mathrm{~mm}$.

Fig. 5. Margin feeding $(1,2)$, hole feeding $(8,10)$, surface feeding (3-7), piercing-and-sucking (11-13), and galling $(8,9)$ on gigantopterids. DT143 on Zeilleropteris is at 1 (USNM 612217), enlarged at 2. DT29 on Zeilleropteris is at 3 (USNM 612216), enlarged at 4. DT30 and DT31 on Cathaysiopteris are at 5 (USNM 612221), with both DTs enlarged at 6 and DT30 enlarged at 7. Hole feeding (DT02) and a new gall damage type (DT267) on Zeilleropteris are at 8 (USNM 612222), with the gall (DT267) enlarged at 9 and hole feeding (DT02) enlarged at 10. DT46 on Zeilleropteris is at 11 (USNM 616673), enlarged at 12 and 13. Scale bars: solid black, $10 \mathrm{~mm}$; solid white, $1.0 \mathrm{~mm}$; dashed, $0.1 \mathrm{~mm}$. 
Fig. 6. Seed predation. DT74 on Seed type 1, a small unwinged seed, is at 1 (USNM 612214). DT73 on Seed type 2, a large samaropsid winged seed, is at 2 (USNM 612226) and enlarged at 3. DT74 on Seed type 2 is at 4 (USNM 612224), enlarged at 5 and 6, and DT74 on another Seed type 2 specimen at 7 (USNM 612218). DT124 on Seed type 2 is at 8 (USNM 612219), enlarged at 9. Scale bars: solid black, $10 \mathrm{~mm}$; solid white, $1.0 \mathrm{~mm}$; dashed, $0.1 \mathrm{~mm}$.

\subsection{External foliage feeding}

External foliage feeding encompasses four basic types of feeding on whole-leaf tissues or their surfaces by insects with mandibulate (chewing) mouthparts that are positioned outside of the consumed leaf. External foliage feeding consists of margin feeding, hole feeding, skeletonization, and surface feeding. Skeletonization absent at MCF and CCP (Schachat et al., 2014), but has been recorded at CBB (Labandeira and Allen, 2007) and Taint (Beck and Labandeira, 1998). Early, well documented skeletonization also has been recorded from the Upper Triassic of China (Feng et al., 2014).

\subsubsection{Margin feeding}

Biology. Margin feeding is the consumption by a mandibulate insect of the entire leaf thickness along its edge. Excisions display reaction tissue at the cut edge that can vary from shallow scallops to deeply notched trenches or more elaborate, polylobate cuts (Johnson and Lyon, 1991).

DTs represented and USNM figured specimens. For DT12: Figs. 3.3-3.5 (USNM 612223); 4.9 (USNM 612206). For DT13: Figs. 3.1, 3.2 (USNM 612215). For DT143: Figs. 3.6-3.8 (USNM 612212); 5.1, 5.2 (USNM 612217).

Plant hosts. The probable cycadophyte Taeniopteris spp. (exemplified by USNM 612223), the gigantopterid Zeilleropteris sp. (exemplified by USNM 612217), and Pteridosperm foliage types 1 (exemplified by USNM 528186) and 2 (exemplified by USNM 528160). 
Remarks. Margin feeding was the most common external-foliage-feeding subgroup at MCF, accounting for 13 of the 24 incidences of external foliage feeding (54.2\%). Similarly, margin feeding was the most common external-foliage-feeding subgroup at other early Permian sites in Texas for which FFG quantitative data has been recorded: CBB (Labandeira \& Allen, 2007) and CCP (Schachat et al., 2014). At MCF, 9 of 13 occurrences of margin feeding (69.2\%) occurred on Taeniopteris spp. DT12 was the most common type of margin feeding across the flora (Figs. 2.32.5; 3.9). Taeniopteris spp. also had one of two records of DT13 (Figs. 3.1, 3.2). This DT was more common at CBB (Labandeira and Allen, 2007), and was found only once at CCP (Schachat et al., 2014). DT143, a distinctive type of margin feeding with continuous, adjacent excisions, occurs at MCF on Taeniopteris spp. (Figs. 2.6-2.8) and on the gigantopterid Zeilleropteris sp. (Figs. 5.1, 5.2).

Paleozoic occurrences. The earliest instance of margin feeding was recently documented as shallow excisions of DT12 and DT13 on the liverwort Metzgeriothallus sharonae from the late Middle Devonian of New York state, U.S.A. (Labandeira et al., 2013). The next most recent occurrence of margin feeding, as DT12, originates from the Late Mississippian of the Sydney Basin, New South Wales, Australia, on the pteridosperm Triphyllopteris austrina (Iannuzzi and Labandeira, 2008). DT12 is a distinctive type of external feeding, also known as the ichnotaxon Phagophytichnus ekowskii (van Amerom, 1966) that occurs extensively on the pteridosperm Macroneuropteris scheuchzeri during the Middle and Late Pennsylvanian (Scott and Taylor, 1983; Castro, 1997; Labandeira, 2013). A somewhat broader spectrum of margin feeding occurs overwhelmingly on glossopterid hosts, from Permian, glossopterid-dominated floras of various regions in Gondwana (Plumstead, 1963; Prevec et al., 2009; Cariglino and Gutiérrez, 2011; Pinheiro et al. 2012; Slater et al., 2012; Labandeira and Prevec, 2014; Gallego et al. 2014), and also from a broader spectrum of hosts from Permian Euramerica (Beck and Labandeira, 1998; Vasilenko, 2007; Labandeira and Allen, 2007; Schachat et al., 2014). 


\subsubsection{Hole feeding}

Biology. The second subgroup of external foliage feeding is hole feeding, wherein a mandibulate insect gains purchase on a leaf by chewing through the interior of the lamina and creates a hole. The resulting damage to the leaf has no defined shape and may be circular, ovoidal, a lobate polygon, a parallel-sided slot, or an elongate multibranched slit (Johnson and Lyon, 1991; Labandeira et al., 2007). A reaction rim, whether well- or poorly developed, almost always borders the margin of the hole.

DT represented and USNM figured specimens. For DT02: Figs. 5.8, 5.10 (USNM 612222).

Plant hosts. The probable cycadophyte Taeniopteris spp. (exemplified by USNM 616671), the gigantopterids Zeilleropteris sp. (exemplified by USNM 612222) and cf. Zeilleropteris (USNM 528159), and the peltasperm cf. Comia (USNM 616672).

Remarks. Hole feeding represents seven out of 24 occurrences of external foliage feeding at MCF (29.2\%), and consists exclusively of DT02. Hole feeding was as widely distributed across plant taxa as any other functional feeding group or subgroup. Along with surface feeding, hole feeding was one of only two functional feeding (sub)groups more commonly found on gigantopterids than on Taeniopteris. The majority of hole-feeding incidences (4 out of 7) were on Zeilleropteris (Figs. 5.8, 5.10).

Paleozoic occurrences. Hole feeding is considerably rarer than margin feeding throughout the late Paleozoic. The earliest occurrence of hole feeding, as DT01, is on the liverwort Metzgeriothallus sharonae from the Middle Devonian of New York state (Labandeira et al., 2013). Apparently, no hole feeding is recorded from any Pennsylvanian-age flora. Several holefeeding DTs occur sporadically throughout the Permian, from floras of Euramerica (Beck and Labandeira, 1998; Vasilenko, 2007; Labandeira and Allen, 2007; Labandeira, 2012), Gondwana (Gallego et al., 2003; Prevec et al., 2009; Cariglino and Gutiérrez, 2011; Slater et al., 2012; Pinheiro et al., 2012; Labandeira and Prevec, 2014; Gallego et al., 2014), and Cathaysia (Glasspool et al., 2003). Collectively, the range of Permian hole-feeding DTs extends to a variety 
of sizes, polylobate shapes, slot feeding, and other types of intercostal excisions (DT01, DT02, DT03, DT04, DT05, DT07, DT08, and DT78), representing a significant expansion of feeding styles from that of previous floras.

\subsubsection{Surface feeding}

Biology. The third subgroup of external foliage feeding is surface feeding, in which the entire thickness of the leaf is not consumed. Rather, the insect removes one or more surface layers, such as the epidermis singly, often including the hypodermis. Surface-feeding insects have

mandibulate mouthparts and feed by rolling up, delaminating or abrading tissue layers exposed at the leaf surface. Such feeding results in damage that often appears as a thin, discolored region in which layers have been removed, revealing exposed, inner tissues surrounded by a rim of callus.

DTs represented and USNM figured specimens. For DT29: Figs. 5.3, 5.4 (USNM 612216). For DT30 and DT31: Figs. 5.5-5.7 (USNM 612221).

Plant hosts. The probable cycadophyte Taeniopteris spp. (exemplified by USNM 612212) and the gigantopterids Cathaysiopteris sp. (exemplified by USNM 612221) and Zeilleropteris sp. (exemplified by USNM 612216).

Remarks. Like hole feeding, surface feeding was more common on gigantopterids (Zeilleropteris, Cathaysiopteris) than on Taeniopteris at MCF, mirroring the pattern at the slightly older gigantopterid-dominated Taint locality (Beck and Labandeira, 1998). One MCF specimen, Cathaysiopteris, exhibits DT30 and DT31 (Figs. 5.6 to 5.8), These two DTs vary only in shape, and likely represent two manifestations of the same surface-feeding behavior by one insect-herbivore taxon.

Paleozoic occurrences. Like margin- and hole feeding, surface feeding, represented by DT29 and DT30, was present by the late Middle Devonian on the liverwort Metzgeriothallus sharonae (Labandeira et al. 2013). This type of surface abrasion and delamination of tissues by mandibulate mouthparts is next found on Middle and Late Pennsylvanian pinnules of the 
pteridosperm Macroneuropteris scheuchzeri (DT75, DT97) from several Euramerican localities (Scott and Taylor, 1983; Labandeira, 2013). During the Permian, evidence of surface feeding is rare to absent in virtually all floras examined, but when present, has been found to occur on seed plants such as medullosans, gigantopterids, callipterid peltasperms, and taeniopteroid cycadophytes (Beck and Labandeira, 1998; Vasilenko, 2007; Prevec et al., 2009; Labandeira, 2012; Labandeira and Prevec, 2014; Schachat et al., 2014). The variety of surface-feeding damage increases markedly during the Middle Pennsylvanian and through the early Permian to include approximately ten DTs that collectively indicate an expansion of morphologies, autecologies, and behaviors associated with feeding on epidermal and immediately underlying tissues.

\subsection{Piercing-and-Sucking}

Biology. Piercing and sucking involves the penetration of plant tissue by an externally positioned insect whose mouthparts contain an ensemble of stylets, typically of one or two pairs, that puncture the epidermis and often penetrate into deeper tissues (Weber, 1930). The puncture is surrounded by an enclosing, leathery structure, outside of which is a cylindrical zone of anomalous reaction tissue that forms on the epidermal surface a torus-like ring of upraised callus that surrounds the central hole. The foliar evidence for piercing and sucking is related to the cross-sectional shape and size of the piercer-and-sucker's stylet fascicle and can vary from circular to broadly ellipsoidal to lenticular, and whose inner area can be cratered or have a central boss, but lacks a second, inner rim as in larger ovipositional damage. Piercing-and-sucking punctures occur singly, in clusters, as elongate feeding trails or other patterns that indicate targeting of particular tissues (Labandeira et al., 2007).

DTs represented and USNM figured specimens. For DT46: Figs. 5.11-5.13 (USNM 616673). For DT48: Figs. 3.12, 3.13 (USNM 612210). 
Plant hosts. The probable cycadophyte Taeniopteris spp. (exemplified by USNM 612210) and the gigantopterid Zeilleropteris sp. (exemplified by USNM 616673).

Remarks. Piercing-and-sucking occurred as DT46 and DT48, consisting of simple, unadorned puncture marks left by the insertion of stylate mouthparts into plant tissue. This damage affected mostly Taeniopteris, attributable to three out of four total occurrences in the flora. These DTs may have been inflicted by either more specialized, small-bodied lineages of paleodictyopteroid insects (Labandeira and Phillips, 1996a), or by similarly small-bodied early hemipteroid insects (Shcherbakov, 2000). More advanced piercing-and-sucking behaviors, such as scale feeding, typically indicated by circular or ellipsoidal scar tissue and impressions on plant surfaces, were not found at MCF.

Paleozoic occurrences. Piercing and sucking is the only common, functional feeding group that often is preserved in three-dimensionally preserved silica and carbonate permineralizations as well as in two-dimensionally preserved adpression deposits (Shute and Cleal, 1987). The earliest occurrence of piercing and sucking is in silica-permineralized early land-plant stems from the Early Devonian Rhynie Chert, Scotland (Labandeira, 2007). During the late Middle Devonian of New York, the liverwort Metzgeriothallus sharonae exhibits three types of punctures - DT46, DT138, and DT273 - that indicate targeting of particular plant-host cell types. There are no other published records of piercing-and-sucking damage occurring during the Late Devonian and Mississippian, but Pennsylvanian carbonate-permineralized coal balls reveal several threedimensional ensembles of stylet tracks in fern petioles (Scott and Taylor, 1983; Labandeira and Phillips, 1996a). All subsequent, Permian examples of piercing and sucking are in adpression specimens, and represent a small expansion of feeding modes (DT46, DT47, DT48, DT138) inflicted by paleodictyopteroid and hemipteroid insects (Carpenter, 1971) that include the tracking of vascular tissue along the midveins of glossopterid leaves (Prevec et al., 2009). Piercing-and-sucking aphidomorphs that could have created the observed damage patterns are known from middle Permian (Guadalupian) Euramerican deposits (Szwedo et al., 2015) 
One notable clade of piercers and suckers is Coccoidea, or scale insects. This group of Hemiptera apparently originated during the early Permian, and leaves large, distinctive, circular to ovoidal scars. A diversity of scale DTs has been documented at CCP (Schachat et al., 2014), but no such DTs have been found at MCF.

\subsection{Oviposition}

Biology. The oviposition of insect eggs into epidermal and other surface tissues of plants is accomplished by an elongate, typically sword-like structure, with slicing, serrated edges located along the female's abdominal terminus. An ovipositor can insert one or more eggs into shallow or deeper plant tissues, producing a circular-ovoidal to more commonly highly elliptical-lenticular lesions. Each lesion frequently has an outer rim of callus or reaction tissue that surrounds a more modestly developed inner rim which occasionally contains evidence for a partially inserted, ovoidal egg (Labandeira and Currano, 2013). Ovipositional lesions can occur singly or in complex, parallel or arcuate rows of lesions (Hellmund and Hellmund, 1996).

DTs represented and USNM figured specimens. For DT76: Figs. 3.18, 3.19 (USNM 612213). For DT101: Figs. 3.18, 3.20 (USNM 612213). For DT100: Figs. 3.14-3.17 (USNM 612220). For DT246: Figs. 4.13, 4.14 (USNM 612225).

Plant hosts. The probable cycadophyte Taeniopteris spp. (exemplified by USNM 612213) and the gigantopterid Cathaysiopteris sp. (exemplified by USNM 616674).

Remarks. Oviposition occurs most often on Taeniopteris spp. leaves (five out of six cases). DT246 is known only from the early Permian of Texas; it was initially discovered at CCP where it occurred on a wider variety of hosts (Schachat et al., 2014). DT76 and DT101 were jointly found on one Taeniopteris spp. specimen (USNM 612213), and may have been made by the same ovipositing insect. The scars representing DT76 and DT101 are broadly lenticular and measure approximately $2 \mathrm{~mm}$ by $1 \mathrm{~mm}$ and are strongly aligned along a leaf venation pattern with DT76 on primary veins and DT101 on secondary veins or adjacent intercostal tissue. The less common 
DT100 was found on one small Taeniopteris spp. fragment (USNM 612220) that exhibits numerous oviposition scars.

Paleozoic occurrences. Ovipositional damage is first recognized during the middle Pennsylvanian, as large, lenticular lesions in calamite and other sphenopsid stems (Béthoux, 2004) and during the late Pennsylvanian as lenticular lesions on an unidentified leaf (Laaß and Hoff, 2014). The predominance of oviposition on plant axes continues throughout the Permian (Labandeira, 2006a, 2006b), but largely becomes supplemented by foliar oviposition, particularly on Gondwanan, glossopterid-based floras (Prevec et al., 2009; McLoughlin, 2011; Pinheiro et al., 2012; Labandeira and Currano, 2013; Labandeira and Prevec, 2014; Gallego et al., 2014). However, oviposition is poorly represented in Euramerican floras and is principally known from the CCP locality (Schachat et al., 2014) and limited occurrences in European Russia (Vasilenko, 2011). The expansion of ovipositional DTs ranges from one or two on stems during the later Pennsylvanian to at least 12 DTs by the end of the Permian. This increase in ovipositional damage is associated with DTs typified by a large variety of sizes, shapes, and internal textural features that likely were associated with ovipositor structural modifications (Carpenter, 1971; Labandeira, 2006a). During the Permian, ovipositing insects evolved a broader repertoire of behaviors that involved new, complex modes such as linear and arcuate files of lesions in parallel rows.

\subsection{Galling}

Biology. A gall is an anomalous, three-dimensional, tumor-like structure made by an inducing mite or insect — less commonly a bacterium, fungus, or nematode - that results from the hormonal commandeering of a plant host to produce anomalous, atypical tissues (Meyer, 1987; Labandeira and Prevec, 2014). Gall induction can occur during oviposition or when a nymph or larva emerges from an egg that has been inserted into plant tissue. During insect development, hormones are secreted to co-opt the plant host's developmental genetic machinery into serving 
the immature insect's needs. Diversion of normal plant development to produce anomalous tissues forming a gall involves three processes (Meyer, 1987). First is the modification of the plant vasculature to supply water and nutrients to the emerging gall. Second is creation of an inner, meristematic-like, zone of nutritive tissue on which the nymph or larva feeds. Third is the production of outer, hardened tissue, such as sclerenchyma, that protects the chamber-inhabiting nymph or larva from external threats. These three processes of gall formation occur simultaneously and continually while the developing galler increases in size and end immediately before the galler emerges.

DTs represented and USNM figured specimens. For DT32: Figs. 4.11, 4.12 (USNM 612208). For DT80: Figs. 4.9, 4.10 (USNM 612209). For DT247: Figs. 4.13-4.15 (USNM 612225). For DT265: Figs. 4.1-4.4 (USNM 612207). For DT266: Figs. 3.18 (USNM 612213); 4.5-4.8 (USNM 612211). For DT267: Figs. 5.8, 5.9 (USNM 612222).

Plant hosts. The probable cycadophyte Taeniopteris spp. (exemplified by USNM 612208), the gigantopterid Zeilleropteris sp. (exemplified by USNM 612222), and Indeterminate broadleaf (exemplified by USNM 616675).

Remarks. In both the number of incidences (17) and in the variety of DTs (6), galling is ubiquitous at MCF and comparable in abundance to external foliage feeding. Taeniopteris spp. represents $82.4 \%$ (14 out of 17) of all occurrences of galling. In two cases, galls were assigned to the generalized gall morphology of DT32 (Figs. 4.11, 4.12). DT80 was the only gall type found on multiple plant hosts, Taeniopteris, Zeilleropteris, and indeterminate pinnate-broadleaved foliage (Figs. 4.9, 4.10). The DT80 galls are typically circular on Taeniopteris spp. but were more broadly ellipsoidal on Zeilleropteris. DT247 was found only once, on the same Taeniopteris specimen (USNM 612225) that contained DT246 (Figs. 4.13, 4.15). Both DT246 and DT247 are present at CCP. The gall morphotypes DT265, DT266, and DT267 all are new for MCF (see new DTs below). 
Paleozoic occurrences. The earliest known galls are on a land plant from the late Middle Devonian of New York state, U.S.A., the liverwort Metzgeriothallus sharonae. This liverwort supported small, simple galls that were positioned on elongate water- and nutrient conducting cells and may have been induced by a mite (Labandeira et al., 2013). Galls do not occur in the more recent fossil record until the Pennsylvanian. These later Paleozoic galls are an order of magnitude larger, more thickened, and occur exclusively on axes such as fern petioles (Labandeira and Phillips, 1996b) and sphenopsid terminal strobili (van Amerom, 1973). Later, during the early Permian, conifer vegetative buds also were attacked (Labandeira and Allen, 2007). These galls on plant axial organs likely were induced by insects and persist until the early Permian (Stull et al., 2013), at which time there is the emergence of novel, smaller gall types on a variety of seed-plant foliage (Stull et al., 2013; Schachat et al., 2014). Euramerican foliar galls of the earlier Permian included ten morphotypes on medullosan pteridosperms, walchian coniferophytes, callipterid peltasperms, gigantopterids, and probable cycadophytes (Florin, 1945; Labandeira and Allen, 2007; Vasilenko, 2007; Stull et al., 2013; Schachat et al., 2014; Schachat and Labandeira, 2015). In Gondwana, galls are less diverse, occur in deposits from the later Permian, and include approximately five different morphotypes on all anatomical parts of glossopterid leaves (Pant and Srivastava, 1995; Prevec et al., 2009; McLoughlin, 2011).

\subsubsection{New Damage Type: DT265.}

Description. Distinct, circular galls ca. $1.0 \mathrm{~mm}$ in diameter with a broad zone of altered host tissue encompassing a dark, circular, occasionally eccentrically positioned central chamber ca. $0.2-0.3 \mathrm{~mm}$ in diameter and often bearing a central, peaked eminence. These galls occur as solitary individuals or diffuse clusters often fused or otherwise coalesced with adjacent galls, acquiring greater thickness along the surrounding rim as they reach maturity.

DT265 figured specimens. Figs. $4.1-4.4$ (USNM 612207).

DT265 plant host. The probable cycadophyte Taeniopteris spp. 
Remarks: A single, heavily galled Taeniopteris spp. leaf harbored several, distinctive DT265 galls (Figs. 4.1 -4.4). These galls appear to be highly stereotyped and uniform in shape, size, and internal features. DT265 galls are very similar to modern Carulaspis visci (Hemiptera: Diaspididae) galls described by Goidianich (1960) on the angiosperm Viscum album (Viscaceae), a mistletoe. The dark, central area of these galls is enclosed in a central cavity inhabited by an armored scale insect. The chamber-inhabiting insect galler induces growth of a surrounding circular rim of tissue by cellular hypertrophy. These galls occur as solitary individuals or diffuse clusters, often fused or otherwise coalesced with adjacent galls, acquiring greater thickness along the surrounding rim and becoming woody upon maturation.

\subsubsection{New Damage Type: DT266}

Description. Broadly ovoidal to elliptical, galls of uniform size major-axis length $0.1-0.5 \mathrm{~mm}$, most commonly $0.1-0.3 \mathrm{~mm}$, consisting at maturity of a prominent outer, upraised rim and a central circular dome, the latter is separated from the outer rim by an encircling sulcus. The gall is thick, apparently penetrating deep into host tissue and becoming columnar at maturity.

DT266 figured specimens. Figs. 3.18 (USNM 612213); 4.5 - 4.8 (USNM 612211).

DT266 plant host. The probable cycadophyte Taeniopteris spp.

Remarks. DT266 was the second most common DT at MCF, occurring six times, always on Taeniopteris spp. Some of these galls possess a similarity to DT80, which consists of small, round galls in the range of $0.1-1.0 \mathrm{~mm}$ and lack an upraised rim and encircling sulcus. All leaves with DT266 were extensively attacked, and contain numerous, possibly hundreds of galls. The DT266 galls apparently penetrate deep into host tissue and bear a strong, superficial resemblance to scale-insect galls of Frenchia semioculta (Hemiptera: Brachyscelidae) on the angiosperm Casuarina sp. (Casuarinaceae), the she-oak from Australia (Houard, 1923). The modern genus occurs on twigs and small branchlets, produces excrescences on cortical tissues, and has a circular 
to broadly ellipsoidal central chamber that develops at maturity into an ostiole, presumably associated with the emergence of the scale insect (Maskell, 1894).

\subsubsection{New Damage Type: DT267}

Description. A distinctive, lobate foliar gall emerging from a central secondary vein, ca. 3.0 by $4.0 \mathrm{~mm}$ in size, with an irregular margin whose pustulose lobes (bladders?) measure 1.5 by 2.0 $\mathrm{mm}$ in dimension. The gall is surrounded by unaffected epidermal tissue and embeds distinctively altered secondary and tertiary veins. The gall can appear as a spot embedded with altered secondary and tertiary veins.

DT267 figured specimens. Figs. 5.8, 5.9 (USNM 612222).

DT267 plant host. The gigantopterid Zeilleropteris sp.

Remarks. One gall of DT267 has been identified, occurring on a leaf fragment of the gigantopterid Zeilleropteris sp. (USNM 612222). These galls are preserved as a reddish brown cast surrounded by blackish unaffected, epidermal tissue. This gall bears a general resemblance to a common gall morphotype made by mites in the genus Eriophyes (Acari: Eriophyidae). In particular, DT267 is similar to Eriophyes unonae galls on Desmos chinensis (Annonaceae), an angiosperm occurring on the island of Java, Indonesia (Docters van Leeuwen-Reijnvaan and Docters van Leeuwen, 1926). Host-plant tissue modification of this gall includes the formation of bulbous bladders (Houard, 1923; Docters van Leeuwen-Reijnvaan and Docters van Leeuwen, 1926; Meyer, 1987), similar to the lobed structures of the DT267 gall.

\subsection{Seed Predation}

Biology. Seed predation is defined as the consumption by insects of inner, nutritive central bodies of seeds, such as the megagametophytic tissues of gymnosperms and the endosperm of angiosperms. Because these tissues also are adjacent to or incorporate the embryonic tissues, their consumption is considered predation, as the plant embryo is killed. Several feeding guilds engage 
in seed predation, and the three most common modes are: (i) damage caused by externally feeding, mandibulate insects; (ii) lesions inflicted by piercing-and-sucking insects; and (iii) galls made by seed galling insects (Louda, 1982; Johnson and Lyon, 1991).

DTs represented and USNM figured specimens. For DT73: Figs. 6.2, 6.3 (USNM 612226).

For DT74: Figs. 6.1 (USNM 612214), 6.4-6.6 (USNM 612224), 6.7 (USNM 612218). For

DT124: Figs. 6.8, 6.9 (USNM 612219).

Plant hosts. Indeterminate seed plants of Seed type 1 (small, unwinged seed; exemplified by USNM 612214) and Seed type 2 (large, samaropsid winged seed; exemplified by USNM 612226).

Remarks. Seed predation was far more common on type 2 than on the more numerous small seeds of type 1. Only one Seed type 1 specimen (USNM 612214) contained evidence of predation: a single hole of DT74 (Fig. 6.1). Type 2 seeds show six instances of predation: DT74 occurs four times (Figs. 6.4-6.7), DT73 is present once (Figs. 6.2, 6.3), and DT124 also occurs once (Figs. 6.8, 6.9). This is the first reported occurrence of DT124 in the early Permian of Texas.

Paleozoic occurrences. Compared with other FFGs, seed predation appears highly delayed as a potential feeding strategy for late Paleozoic insect herbivores. The earliest known seed predation occurs on Trigonocarpus seeds of medullosan pteridosperms in the Euramerican Early Pennsylvanian (Labandeira, 2007). During the Middle Pennsylvanian, the winged cordaitalean seed, "Samaropsis", of the Tugunska Basin in Siberian Russia, provides excellent evidence for seed predation, probably made by a paleodictyopteran insect (Sharov, 1973). Although a few other examples of seed predation are known from the Permian (Shcherbakov, 2008; Schachat et al., 2014), the occurrence of this FFG throughout the late Paleozoic is very rare. This observed pattern seems incongruous, given that megagametophytic and embryonic tissues apparently were plentiful and available for consumption, frequently as large seeds. Potential food offered by large seeds could have been unavailable to predators possibly due to the presence of thick, sclerotic or 
otherwise highly defended inner tissues (Taylor, 1965), or perhaps seed predators had not evolved mouthpart structures to penetrate thickened physical structures (Labandeira, 1997).

\section{Discussion}

Several features of the damage spectrum at MCF warrant further discussion. The observed patterns include the preferential targeting of one particular host, much of it specialized, and the lack of significant levels of herbivory on the remaining hosts. There also are distinctive relationships between MCF and similar floras from the early Permian of north-central Texas, indicating establishment of some general trends in herbivory. In this regard, we conducted a multivariate analysis, which in conjunction with other observations, indicate that local, sitespecific processes best explain the patterns of herbivory, rather than coarser-grained, host-plant categorizations at approximately the level of the order. The site-specific processes involve ecological preferences of the host plants at the lowest taxonomic resolution, primarily at the level of the genus and would include effects of differing environments. In addition, it appears that time is not an important variable accounting for changes in patterns of herbivory among the four localities analyzed to date.

\subsection{Habitat, plant-host, and tissue specificities of Mitchell Creek Flats insect herbivores}

Over half of all herbivorized specimens at MCF are Taeniopteris spp. leaves. Taeniopteris spp. also is the only taxon with a significantly elevated herbivory index (2.66), which is over five times higher than that of the next most heavily attacked taxon, Cathaysiopteris sp. (0.51). Six DTs (DT32, DT48, DT76, DT100, DT246, and DT247) are found only on Taeniopteris spp. and two of the three new gall DTs (DT265, DT266) occur solely on Taeniopteris spp., demonstrating a significant degree of host-specificity. Among the gigantopterids, Zeilleropteris sp. had the highest proportion of herbivorized leaves based on qualitative presence/absence data. 
Cathaysiopteris sp. had the highest average herbivorized surface area but is represented by very few specimens, only two of which were herbivorized. Besides Taeniopteris spp. and the gigantopterids, the only broadleaf taxon represented by more than three specimens was the peltasperm ?Rhachiphyllum; this foliage type was not herbivorized. Insect herbivores at MCF exhibited a clear preference for the most abundant or most apparent foliar taxon, Taeniopteris spp., although minimal but nevertheless proportionately greater herbivory was present in the second most abundant group, the gigantopterids. This pattern of herbivory suggests that the herbivores at MCF, like many modern herbivores, preferentially targeted more common and conspicuous taxa (Hacker and Bertness, 1995; Turcotte et al., 2014). These observations are consistent with the plant apparency hypothesis of Feeny (1976). Given that MCF is a channel-fill deposit adjacent to riparian shrubland or woodland that included various woody gigantopterids, peltasperms, and conifers, it was the particular dominance of Taeniopteris spp. that sustained a wide variety of insect herbivores.

\subsection{Associations at Mitchell Creek Flats compared to the other early Permian Texas localities}

Floristically, the closest flora to MCF is CCP. MCF has only $38.3 \%$ as many specimens as the somewhat younger CCP site (820 versus 2140). Nevertheless, MCF shares two similarities with CCP: both have similar indices of herbivory, 1.98 versus 2.34 , and more importantly, both have a well-balanced representation of DTs and FFGs forming a component community (Root, 1973). This balance suggests a slimmed down version of CCP's well-balanced spectrum of component communities (Tables 2, 3). Component communities consist of all organisms that ecologically are dependent on a particular resource (Root, 1973) - in this case the host plants Taeniopteris spp.

Perhaps the best modern example of a component community of arthropod herbivores is the North American milkweed genus Asclepias (Apocynaceae), which has an assemblage of insects that represent a full complement of FFGs. Modern Asclepias sp. has all of the FFGs present on Taeniopteris spp., in addition to leaf miners, pith borers, and pollinators (Farrell, 2001; Agrawal, 
2005). As a source host plant, modern Asclepias and its dependent herbivores (and their consumers) are completely different taxonomically from Taeniopteris spp. in the early Permian. However, the FFGs forming the component communities of both plants had the same ecological roles. Asclepias has a larger set of FFGs than Taeniopteris spp. because the additional FFGs accumulated evolutionarily more recently and for a longer duration than those of the early Permian. At least on arborescent plants, fully developed component communities were present on such Paleozoic plants as the Late Pennsylvanian marattialean fern Psaronius sp. (Labandeira, 1998; Rößler, 2000), the late Permian Glossopteris sp. (Slater et al., 2012), and, at least for foliage FFGs, the early Permian Taeniopteris spp. These data indicate that the "self-assembly" of insect herbivores into a more-or-less complete spectrum of FFGs may be a fundamental aspect of the evolution of arthropod herbivores (Futuyma and Mitter, 1996). This parallels other deep-time evolutionary and ecological processes such as host-plant shifts, diversification events of plants and their insect associates, as well as an overall increase in herbivory of the host plants (Futuyma and Agrawal, 2009; Turcotte et al., 2014).

The distribution of multiple DTs, often five or six per FFG, in external foliage feeding, oviposition, and galling at MCF (Table 2) mirrors the distribution of herbivory at CCP (Schachat et al. 2014). The proportional distributions of FFGs at the MCF and CCP floras are approximately equivalent when the greater number of CCP specimens is taken into account. Of the five FFGs at MCF, external foliage feeding is less prevalent relative to the other four (Table 3). It is perplexing that the only FFG present at Taint is that of external foliage feeding even though the composition of the flora is quite similar at both MCF and Taint. By contrast, piercing and sucking, and oviposition are well represented at MCP and CCP, but absent at Taint and CBB. The absence of these two "puncturing" FFGs at Taint and CBB is curious, as insects responsible for both types of damage, particularly Palaeodictyopteroidea and Hemipteroidea, occur abundantly in early Permian deposits throughout Euramerica (Novokshonov, 1998; Beckemeyer, 2000; Shcherbakov, 2000). The possibility remains that recognition of piercing and sucking at Taint could have been 
taphonomically suppressed, although other delicate types of external foliage feeding was detected at Taint. No seeds from Taint or CBB were examined; the occurrence of seed predation is highly variable across these floras.

Table 3. Quantitative and qualitative comparisons of insect herbivory on broadleaf plant hosts in the early Permian (Cisuralian) of Texas.

\begin{tabular}{|l|c|c|c|c|c|}
\cline { 3 - 6 } \multicolumn{2}{c|}{} & \multicolumn{4}{|c|}{ Number of FFG incidences per 100 specimens } \\
\hline $\begin{array}{c}\text { Site } \\
\text { (chronologically } \\
\text { ranked) }\end{array}$ & $\begin{array}{c}\text { Herbivory } \\
\text { Index }\end{array}$ & $\begin{array}{c}\text { External } \\
\text { Foliage } \\
\text { Feeding }\end{array}$ & $\begin{array}{c}\text { Piercing } \\
\text { and } \\
\text { Sucking }\end{array}$ & Oviposition & Galling \\
\hline Coprolite Bone Bed & 0.27 & 25.58 & 00.00 & 00.00 & 00.19 \\
\hline Taint & 2.58 & 33.20 & 00.00 & 00.00 & 00.00 \\
\hline Mitchell Creek Flats & 1.98 & 12.64 & 02.20 & 03.30 & 09.34 \\
\hline Colwell Creek Pond & 2.34 & 17.28 & 11.39 & 32.27 & 35.36 \\
\hline
\end{tabular}

The DTs of galls are more diverse and frequent at MCF in comparison to the other floras. CBB had only two gall DTs with one occurrence each; Taint lacked identifiable galling; and MCF by contrast has five gall DTs representing diverse morphologies (Table 2). Using the recent analysis of late Paleozoic glaciation cycles of Montañez and Poulsen (2013) and the correlations of Beck and Labandeira (1998), we interpret that both MCF and Taint were deposited during a non-glacial period. In modern ecosystems galls are associated with arid environments (Fernandes and Price, 1988).

\subsection{Additional analyses of herbivory in the early Permian of Texas}

Of the three localities previously analyzed from the early Permian of Texas, Taint and CCP have similar host plants. Gigantopterids are most common at Taint (38.26\% of specimens), followed by Taeniopteris spp. (19.99\%), while at CCP this order is reversed with gigantopterids and Taeniopteris spp. accounting for $1.50 \%$ and $20.09 \%$ of specimens, respectively. The only 
gigantopterid genus found at CCP, Evolsonia, was not found at the other three sites; the 32 Evolsonia specimens examined from CCP show few instances of herbivory. The statistical pattern of herbivory among the four localities appears diffuse, necessitating multivariate comparisons (1) between damaged Taeniopteris spp. and gigantopterids, and (2) among all broadleaf taxa.

When a comparison was made of the functional feeding groups and plant hosts using a nonmetric multidimensional scaling (NMDS) ordination, Taeniopteris spp. and gigantopterid specimens at Taint, MCF, and CCP did not exhibit a clear trend (Fig. 7.1). Both Taeniopteris spp. and gigantopterid taxa from CCP cluster closely together, and both taxa from Taint exhibited only external foliage feeding, and therefore are far removed from the cluster that consists of piercing and sucking, oviposition, and galling. However, the MCF Taeniopteris spp. and gigantopterid taxa have a wide separation from each other and also from their counterparts at other localities. Because the MCF plant hosts cluster closer to CCP than Taint, it appears that separation in time - a proxy association for the replacement of the Paleozoic Insect Fauna by the Modern Insect Fauna-was not the principal determinant of insect herbivory at the three sites. The spaces bounded between each single-taxon couplet do not overlap, which suggests that plant-host affinity at the level of major plant groups also may have been a weak determinant of insect herbivory patterns. Nevertheless, among other plant groups, typically at the genus level, there is evidence for significant host specialization (see Sections 5.1 and 5.2 above), which indicates that site-specific relationships may be the most important factor in determining plant-insect interactions. 


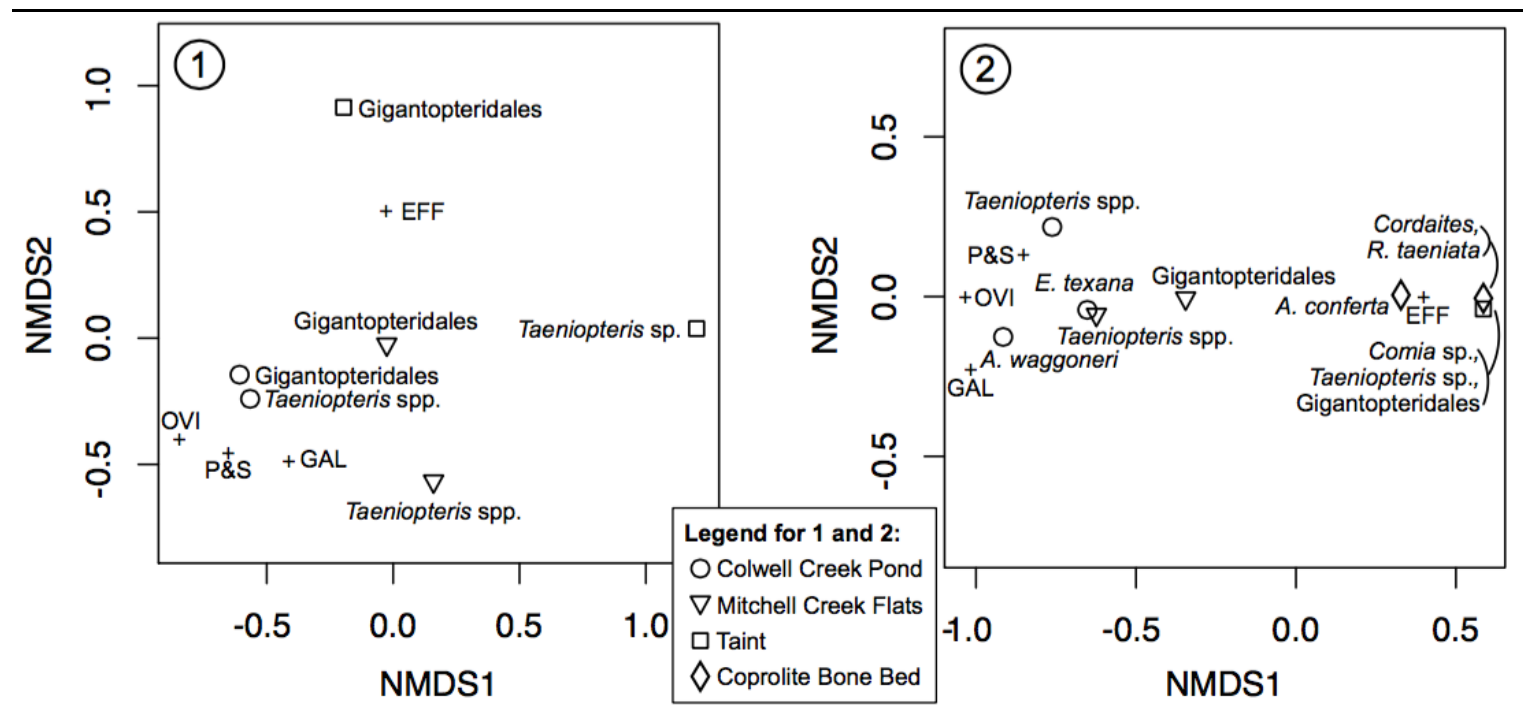

Fig. 7. Non-metric multidimensional scaling (NMDS) ordination of foliage at Coprolite Bone Bed (CBB), Mitchell Creek Flats (MCF), Taint, and Coprolite Bone Bed (CBB) from the early Permian (Cisuralian) of north-central Texas, categorized by functional feeding group (FFG). 1, Taeniopteris spp. and gigantopterid leaves at Taint, $\mathrm{MCF}$, and $\mathrm{CCP}$, based on the relative abundances of insect herbivore damage, categorized by FFG. 2, All broadleaf taxa with abundances greater than 30 specimens, based on the relative abundances of insect herbivore damage, categorized by FFG. Abbreviations: EFF, external foliage feeding; GAL, galling; Gig, gigantopterid taxa; OVI, oviposition; P\&S, piercing and sucking.

When all broadleaf taxa from all four localities of the early Permian of Texas are included in a new ordination (Fig. 7.2), patterns are even less evident. The space between Taeniopteris spp. and the gigantopterid taxa overlap, reducing the likelihood of host-plant affinity as a significant driver of insect herbivory patterns through this interval of time. Taxa at MCF and CCP do not overlap, but closely approach each other. There also appears to be a significant separation between an area expressing the external foliage feeding FFG to the right of the plot, versus the remaining FFGs of piercing and sucking, oviposition, and galling to the left of the plot. This distinctive separation of clusters may indicate a major differentiation between the herbivore 
communities of plant-host taxa at MCF and CCP compared to CBB and Taint. Collectively, these data appear to support an herbivore offensive strategy, in which insect herbivores seize an advantage by minimizing a plant's defensive capability and other vulnerabilities and simultaneously maximizing their feeding efficiency (Rhoads, 1985). An alternative strategy to opportunism is stealth, in which other insect herbivores have low feeding levels, minimize plant damage and consequently reduce the host's defensive response by facilitating accommodation (Rhoads, 1985). Nevertheless, the high levels of herbivory and the establishment of a more balanced spectrum of FFGs on Taeniopteris spp. are consistent with the plant apparency hypothesis of Feeny (1976). The impact of apparency on insect herbivory appears to be quite strong at three of the four sites from north-central Texas (Fig. 8). These three-CBB, MCF, and $\mathrm{CPP}$ - all contain evidence of galls on major broadleaf taxa, whereas insect herbivory at the other site, Taint, is restricted to external foliage feeding.
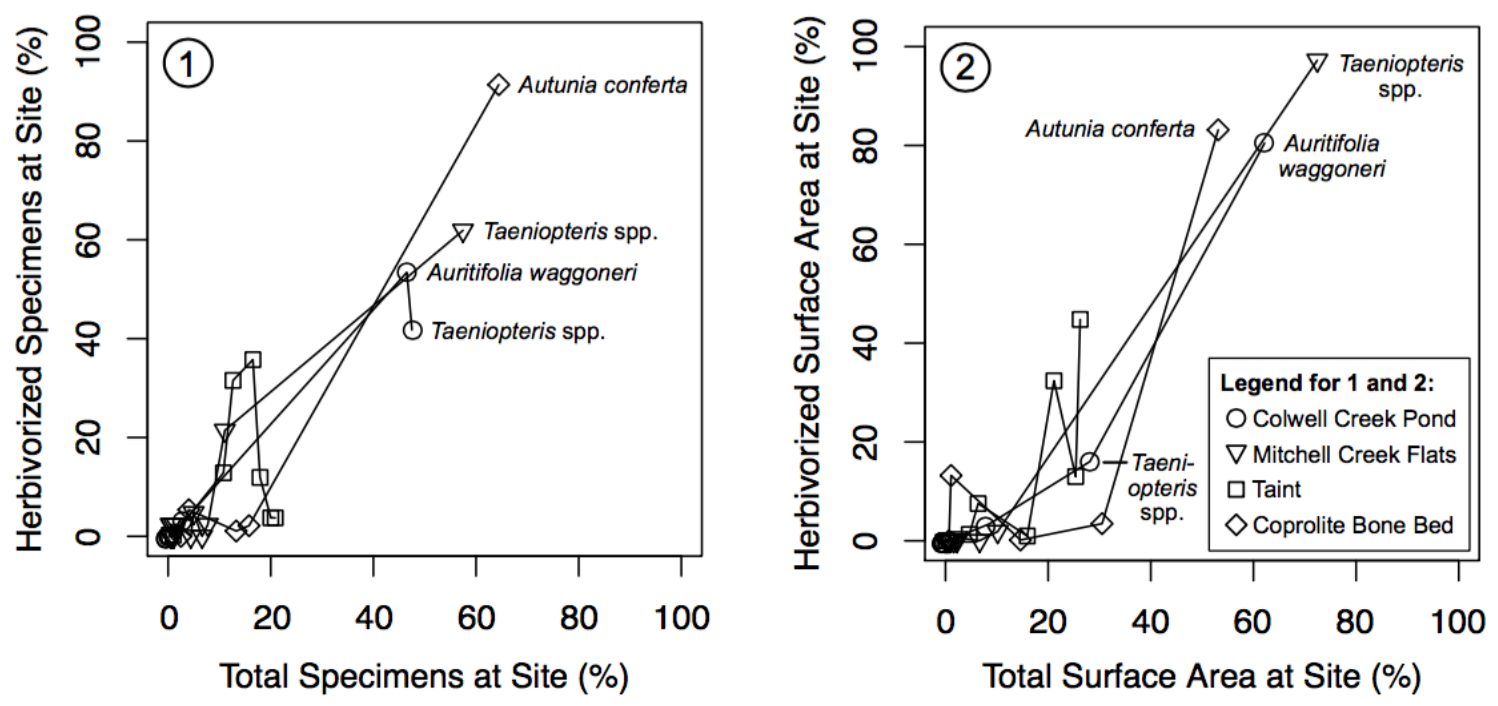

Fig. 8. The relationship between abundance and insect attack for broadleaf taxa at Coprolite Bone Bed (CBB), Mitchell Creek Flats (MCF), Taint, and Coprolite Bone Bed (CBB) from the early Permian (Cisuralian) of north-central Texas. 
Qualitative measures based on frequency (total number of specimens, number of herbivorized specimens) support the apparency hypothesis for $\mathrm{CBB}, \mathrm{MCF}$, and $\mathrm{CCP}$, with the exception of the cycadophyte Taeniopteris spp. at CCP (Fig. 8.1). However, as noted earlier, this Linnaean taxon serves as a form genus and may include a number of different species that would be difficult to distinguish but may be closely or distantly related. Quantitative measures based on leaf surface area also support the apparency hypothesis (Fig. 8.2). The two CCP taxa Auritifolia waggoneri and Taeniopteris spp. were attacked with similar frequency on a specimen-by-specimen basis, but far more surface area was herbivorized on Auritifolia waggoneri than on the form genus Taeniopteris spp. At MCF and CBB, the relationship between apparency and herbivory is unequivocal. These results suggest two tentative conclusions. First, insects began to target the most apparent taxa concurrently with the origin of specialized modes of herbivory such as galling. And second, quantitative and qualitative measures of leaf surface area are more robust to polyphyletic form-taxa because of the potential for foliar heterogeneity and thus greater levels of herbivory. Additional floras from the region should provide further evidence that address this question.

\section{Conclusions}

Although MCF has a modest number of plant specimens, it is nevertheless the most floristically diverse of the four early Permian localities examined from north-central Texas. Three general conclusions can be derived from the results of our study that express the three dynamic features of herbivory at MCF: the presence of a well-balanced component community of herbivores, the extensive development of gall associations, and the importance of herbivore opportunism in plant consumption patterns.

1. A well-balanced spectrum of functional-feeding-groups. MCF shows an elevated frequency of external foliage feeding, piercing and sucking, oviposition, galling, and seed predation. Perhaps more important is the impressive range of DTs for most FFGs: seven external foliage 
feeding DTs, four oviposition DTs, and six galling DTs. This indicates not only a diverse assemblage of herbivores at MCF, but also an eclectic spectrum of plant consumers within most of the major herbivore feeding guilds. This pattern indicates a well-established component community (Root, 1973) for the most herbivorized plant, Taeniopteris spp.

2. The exceptional richness and abundance of galling. The high incidence of galling at MCF is shown by presence of seven galling DTs, three of which are new. This indicates that the galler FFG was well established by the mid early Permian (mid Cisuralian). Earlier galls that have been documented from early to mid Cisuralian regional deposits are quite different from those at MCF (Labandeira and Allen, 2007; Stull et al., 2013; Schachat and Labandeira, 2015). This downward extension of the gall record shows that the antecedents of the MCF foliar gall suite extended regionally to the Pennsylvanian-Permian boundary. In addition, the prevalence of modern galls in extratropical, xeric habitats (Fernandes and Price, 1988) is consistent with dry, somewhat xeric habitats for this locality.

3. Opportunistic host-seeking behavior by insect herbivores. The most abundant foliage at MCF is Taeniopteris spp., representing $47.5 \%$ of all foliage, at five times the prevalence of the next most abundant taxon, Zeilleropteris sp. (9.1\%). Moreover, Taeniopteris spp. accounts for $56.9 \%$ of all interactions at MCF, an additional indication that it was the most intensely herbivorized taxon. Taeniopteris spp. was also the only plant host consumed by the four major broadleaf feeding guilds (see conclusion 1 above). Collectively, these data imply that MCF has the most abundant and conspicuous plants that were opportunistically targeted by generalist and frequently specialized, insect herbivores. This pattern is consistent with the apparency hypothesis of Feeny (1976).

Elucidation of whether the herbivory results at MCF are applicable to the broader sequence of early Permian Floras in north-central Texas would require examination of additional localities. Such studies would provide valuable insight into the evolution of herbivory across these fluvially dominated landscapes. 


\section{Acknowledgments}

Many thanks go to William A. DiMichele for facilitating collections access to MCF material, for assisting in plant identification, and for valuable comments on an earlier draft of this manuscript. Finnegan Marsh provided support and coordinated the assignment of new damage types and placed the figures in correct journal format. Rebecca Koll assisted with plant identification. We are grateful to two anonymous reviewers and to William O. Lamp and Charles Mitter of the Department of Entomology of the University of Maryland, College Park for providing valuable feedback. The Benson Fund and Brown Fund of the Smithsonian Institution's Department of Paleobiology provided funding for the analysis of the MCF flora. This is contribution 274 of the Evolution of Terrestrial Ecosystems consortium at the National Museum of Natural History, in Washington, D.C.

\section{References}

Adami-Rodrigues, K., De Souza, P.A., Iannuzzi, R., Pinto, I.D., 2004. Herbivoria em floras Gonduânicas do Neopaleózoico do Rio Grande do Sul: análise quantitative. Revista Brasileira de Paleontología 7, 93-102. http://dx.doi.org/10.4072/rbp.2004.2.01

Adams, J.M., Zhang, Y., 2009. Is there more insect folivory in warmer temperate climates? A latitudinal comparison of insect folivory in eastern North America. Journal of Ecology 97, 933-940. http://dx.doi.org/10.1111/j.1365-2745.2009.01523.x

Agrawal, A.A., 2005. Natural selection on common milkweed (Asclepias syriaca) by a community of specialized insect herbivores. Evolutionary Ecology Research 7, 651-667.

Araya, J.E., Ormeño, J., Díaz, C.A., 2000. Calidad hospedera de Datura spp. y otras solanáceas para Lema bilineata Germar. Boletin Sanidad de Vegetal y Plagas 26, 65-71.

Banerjee, M., Bera, S., 1998. Record of zoocecidia on leaves of Glossopteris browniana Brongn. from Mohuda Basin, Upper Permian, Indian Lower Gondwana. Indian Biologist 30, 58-61. 
Beck, A.L., Labandeira, C.C., 1998. Early Permian insect folivory on a gigantopterid-dominated riparian flora from north-central Texas. Palaeogeography, Palaeoclimatology, Palaeoecology 142, 139-173. http://dx.doi.org/10.1016/s0031-0182(98)00060-1

Beckemeyer, R.J., 2000. The Permian insect fossils of Elmo, Kansas. Kansas School Naturalist $46,1-15$.

Béthoux, O., 2004. Earliest evidence of insect endophytic oviposition. Palaios 19, 408-413. http://dx.doi.org/10.1669/0883-1351(2004)019\%3C0408:eeoieo\%3E2.0.co;2

Bodnaryk, R.P., 1992. Distinctive leaf feeding patterns on oilseed rapes and related Brassicaceae by flea beetles, Phyllotreta cruciferae (Goeze) (Coleoptera: Chrysomelidae). Canadian Journal of Plant Science 72, 575-581. http://dx.doi.org/10.4141/cjps92-072

Boys, H.A., 1989. Food selection by some graminivorous Acrididae. Ph.D. dissertation, Oxford University, U.K., 239 p.

Brues, C.T., 1924. The specificity of food-plants in the evolution of phytophagous insects. American Naturalist 58, 127-144. http://dx.doi.org/10.1086/279965

Carpenter, F.M., 1971. Adaptations among Paleozoic insects. In: Yochelson, E., (Ed.), Proceedings of the North American Paleontological Convention (1969). Allen Press, Lawrence, Kansas, 2, 1236-1251.

Carpenter, F.M., Burnham, L., 1985. The geological record of insects. Annual Review of Earth and Planetary Sciences, 13, 297-314. http://dx.doi.org/10.1146/annurev.earth.13.1.297

Cariglino, B., Gutiérrez, P.R., 2011. Plant-insect interactions in a Glossopteris flora from the La Golondrina Formation (Guadalupian-Lopingian), Santa Cruz Province, Patagonia, Argentina. Ameghiniana 48, 103-112. http://dx.doi.org/10.5710/amgh.v48i1(321)

Castro, P.M., 1997. Huellas de actividad biológica sobre plantas del Estafaniense Superior de la Magdalena (León, España). Revista Española de Paleontología 12, 52-66.

Chaney, D.S., Sues, H.-D., DiMichele, W.A., 2005. A juvenile skeleton of the nectridean amphibian Diplocaulus and associated flora and fauna from the Mitchell Creek Flats locality 
(upper Waggoner Ranch Formation; Early Permian), Baylor County, north-central Texas, USA. The Nonmarine Permian New Mexico Museum of Natural History and Science Bulletin 30, 39-47.

Chapman, R.F., Joern, A., 1990. Biology of Grasshoppers. John Wiley, New York.

Crame, J.A., 2001. Taxonomic diversity gradients through geological time. Diversity and Distributions 7, 175-189. http://dx.doi.org/10.1046/j.1472-4642.2001.00106.x

Cohen, K.M., Finney, S.C., Gibbard, P.L., Fan, J.-X., 2013 (updated) The ICS International Chronostratigraphic Chart. Episodes 36: 199-204.

Currano, E.D., Labandeira, C.C., Wilf, P., 2010. Fossil insect folivory tracks paleotemperature for six million years. Ecological Monographs 80, 547-567. http://dx.doi.org/10.1890/092138.1

DiMichele, W.A., Cecil, C.B., Chaney, D.S., Elrick, S.D., Lucas, S.G., Lupia, R., Nelson, W.J., Tabor, N.J., 2011. Pennsylvanian-Permian vegetational changes in tropical Euramerica. Geology of the Pennsylvanian-Permian in the Dunkard Basin 60-102.

DiMichele, W.A., Cecil, C.B., Montañez, I.P., Falcon-Lang, H.J., 2010. Cyclic changes in Pennsylvanian paleoclimate and effects on floristic dynamics in tropical Pangaea. International Journal of Coal Geology 83, 329-344. http://dx.doi.org/10.1016/j.coal.2010.01.007

DiMichele, W.A., Gastaldo, R.A., Pfefferkorn, H.W., 2005. Plant biodiversity partitioning in the Late Carboniferous and Early Permian and its implications for ecosystem assembly. Proceedings of the California Academy of Sciences 56, 32-49.

DiMichele, W.A., Montañez, I.P., Poulsen, C.J., Tabor, N.J., 2009. Climate and vegetational regime shifts in the late Paleozoic ice age earth. Geobiology 7, 200-226. http://dx.doi.org/10.1111/j.1472-4669.2009.00192.x

Dixon, T., Thieme, T., 2007. Aphids on Deciduous Trees. Richmond Publishing, Slough, U.K. Dmitriev, V.Y., Zherikhin, V.V., 1988. Changes in the familial diversity of insects and 
demonstration of a method of data analysis. In: Ponomarenko, A.G. (Ed.), The MesozoicCenozoic crisis in the evolution of Insects. Academy of Sciences, Moscow, pp. 208-215 (in Russian).

Docters van Leeuwen-Reijnvaan, J., Docters van Leeuwen, 1926. The Zoocecidia of the Netherlands East Indies. Drukkerij de Unie, Batavia.

Farrell, B.D., 2001. Evolutionary assembly of the milkweed fauna: cytochrome oxidase I and the age of Tetraopes beetles. Molecular Phylogenetics and Evolution 18, 467-478. http://dx.doi.org/10.1006/mpev.2000.0888

Feeny, P., 1976. Plant apparency and chemical defense. In: J. Wallace, and R. Mansell (Eds.), Biochemical Interaction between Plants and Insects. Recent Advances in Phytochemistry 10: 1-40. http://dx.doi.org/10.1007/978-1-4684-2646-5_1

Feng, Z., Su, T., Yang, J.-Y., Chen, Y.-X., Wei, H.B., Dai, J., Guo, Y, Liu, J.-R., Ding, J.-H., 2014. Evidence for insect-mediated skeletonization on an extant fern family from the Upper Triassic of China. Geology 42, 407-410. http://dx.doi.org/10.1130/g35369.1

Fernandes, G.W., Price, P.W. 1988. Biogeographical gradients in galling species richness: tests of hypotheses. Oecologia 76, 161-167. http://dx.doi.org/10.1007/bf00379948

Florin, R., 1945. Die Koniferen des Oberkarbons und des unteren Perms. Palaeontographica, Abteilung B 85, 1-61, pls. 1-30.

Futuyma, D.J., Agrawal, A.A., 2009. Macroevolution and the biological diversity of plants and herbivores. Proceedings of the National Academy of Sciences, U.S.A. 106, 18054-18061. http://dx.doi.org/10.1073/pnas.0904106106

Futuyma, D.J., Mitter, C., 1996. Insect-plant interactions: the evolution of component communities. Philosophical Transactions of the Royal Society of London B 351, 1361-1366. http://dx.doi.org/10.1098/rstb.1996.0119

Gallego, J., Cúneo, R., Escapa, I., 2014. Plant-arthropod interactions in gymnosperm leaves from the Early Permian of Patagonia, Argentina. Geobiology 47, 101-110. 
http://dx.doi.org/10.1016/j.geobios.2014.01.002

Gallego, O.F., Gnaedinger, S., Kirsten, O., Giovanelli, S., 2003. Primera cita de trazas fósiles de insectos en hojas del Pérmico de Uruguay y Triásico de Chile. Comunicaciones Científicas y Tecnológicas Universidad Nacional del Nordeste B-033, 1-5.

Gangwere, S.K., 1966. Relationships between the mandibles, feeding behavior, and damage inflicted on plants by the feeding of certain acridids (Orthoptera). Michigan Entomologist 1, $13-16$.

Glasspool, I., Hilton, J., Collinson, M., Wang, S.J., 2003. Foliar herbivory in Late Palaeozoic Cathysian gigantopterids. Review of Palaeobotany and Palynology 127, 125-132.

Goidianich, A., 1960. Specializzione ecologica e nomenclatura delle Carulaspis del Viscum e della Cupressaceae (Hemiptera, Coccoidea, Diaspididae). Bollettino Istituto Entomología del Bologna 24, 1-38.

Gradstein, FM, Ogg, JG., Schmitz, MD, Ogg, G., 2012. The Geologic Time Scale 2012. Elsevier, Boston.

Hacker, S.D., Bertness, M.D., 1995. A herbivore paradox: why salt marsh aphids live on poorquality plants. American Naturalist 145, 192-210. http://dx.doi.org/10.1086/285736

Hammon, K.E., Faeth, S.H., 1992. Ecology of plant-herbivore communities: a fungal component? Natural Toxins 1, 197-208. http://dx.doi.org/10.1002/nt.2620010307

Haug, J.T., Labandeira, C.C., Santiago-Blay, J., Haug, C., Brown, S., 2015. Life habits, hox genes, and affinities of a 311 million-year-old holometabolan larva. BMC Evolutionary Biology 15. http://dx.doi.org/10.1186/s12862-015-0428-8

Hellmund, M., Hellmund, W., 1996. Zum Fortpflanzungsmodus fossiler Kleinlibellen (Insecta, Odonata, Zygoptera). Paläontologische Zeitschrift 70, 153-170. http://dx.doi.org/10.1007/bf02988274

Henderson, C.M., Wardlaw, B.R., Davydov, V.I., Schmitz, M.D., Schiappa, T.A., Tierney, K.E., Shen, S., 2012. Proposal for base-Kungurian GSSP. Permophiles 56, 8-21. 
Hentz, T.F., 1988. Lithostratigraphy and paleoenvironments of Upper Paleozoic continental red beds, north-central Texas: Bowie (new) and Wichita (revised) Groups. University of Texas Bureau of Economic Geology Report of Investigations 170, 1-55.

Heron, H.D.C., 2003. Tortoise beetles (Chrysomelidae: Cassidinae) and their feeding patterns from the North Park Nature Reserve, Durban, KwaZulu-Natal, South Africa. Durban Museum Novitates 28, 31-44.

Houard, C., 1923. Les Zoocécidies des Plantes d'Afrique, d'Asie et d'Océanie. Volume 1. Jules Hermann, Paris.

Iannuzzi, R., Labandeira, C.C., 2008. The oldest record of external foliage feeding and the expansion of insect folivory on land. Annals of the Entomological Society of America 101, 79-94. http://dx.doi.org/10.1603/0013-8746(2008)101[79:toroef]2.0.co;2

Jarzembowski, E.A., Ross, A.J., 1996. Insect origination and extinction in the Phanerozoic. Geological Society Special Publication 102, 65-78. http://dx.doi.org/10.1144/gsl.sp.1996.001.01.05

Johnson, W.T., Lyon, H.H., 1991. Insects that Feed on Trees and Shrubs, Second edition. Cornell University Press, Ithaca, N.Y.

Kazakova, I.G., 1985. The character of damage to plants by Orthoptera (Insecta) linked to the structure of their mouthparts (on the example of Novosibirsk Akademgorodok fauna). In: G. S. Zolotarenko, (Ed.), Anthropogenic Influences on Insect Communities. Nauka, Novosibirsk, Russia, pp. 122-127 (in Russian).

Keen, F.P., 1952. Insect enemies of western forests, second edition. United States Department of Agriculture Miscellaneous Publications 273, 1-280. http://dx.doi.org/10.5962/bhl.title.65595

Laaß, M., Hoff, C., 2014. The earliest evidence of damselfly-like endophytic oviposition in the fossil record. Lethaia 48, 115-124. http://dx.doi.org/10.1111/let.12092

Labandeira, C.C., 1997. Insect mouthparts: ascertaining the paleobiology of insect feeding strategies. Annual Review of Ecology and Systematics 28, 153-193. 
http://dx.doi.org/10.1146/annurev.ecolsys.28.1.153

Labandeira, C.C., 1998. Early history of arthropod and vascular plant associations. Annual Review of Earth and Planetary Sciences 26, 329-377. http://dx.doi.org/10.1146/annurev.earth.26.1.329

Labandeira, C.C., 2002. The history of associations between plants and animals. In: C.M. Herrera, Pellmyr, O. (Eds.), Plant-Animal Interactions: An Evolutionary Approach. London, Blackwell Science, pp. 26-74, 248-261.

Labandeira, C.C., 2005. The fossil record of insect extinction: new approaches and future directions. American Entomologist 51, 14-29. http://dx.doi.org/10.1093/ae/51.1.14

Labandeira, C.C., 2006a. Silurian to Triassic plant and insect clades and their associations: new data, a review, and interpretations. Arthropod Systematics and Phylogeny 64, 53-94.

Labandeira, C.C., 2006b. The four phases of plant-arthropod associations in deep time. Geologica Acta 4, 409-438.

Labandeira, C.C., 2007. The origin of herbivory on land: Initial patterns of plant tissue consumption by arthropods. Insect Science 14, 259-275. http://dx.doi.org/10.1111/j.17447917.2007.00141.x-i1

Labandeira, C.C., 2012. Evidence for outbreaks from the fossil record of insect herbivory. Barbosa, P., Letorneau, D.K., Agrawal, A.A.(Eds.). Insect Outbreaks Revisited. Blackwell, Oxford, U.K., pp. 269-290. http://dx.doi.org/10.1002/9781118295205.ch13

Labandeira, C.C., 2013. Deep-time patterns of tissue consumption by terrestrial arthropod herbivores. Naturwissenschaften, 100, 355-364. http://dx.doi.org/10.1007/s00114-013-10354

Labandeira, C.C., Allen, E.G., 2007. Minimal insect herbivory for the Lower Permian Coprolite Bone Bed site of north-central Texas, USA, and comparison to other Late Paleozoic floras. Palaeogeography, Palaeoclimatology, Palaeoecology 247, 197-219. http://dx.doi.org/10.1016/j.palaeo.2006.10.015 
Labandeira, C.C., Currano, E.D., 2013. The fossil record of plant-insect dynamics. Annual Review of Earth and Planetary Sciences 41, 287-311. http://dx.doi.org/10.1146/annurevearth-050212-124139

Labandeira, C.C., Johnson, K.R., Lang, P., 2002. A preliminary assessment of insect herbivory across the Cretaceous/Tertiary boundary: extinction and minimal rebound. In: J.H. Hartman, Johnson, K.R., Nichols, D.J., (Eds.). The Hell Creek Formation and the Cretaceous-Tertiary Boundary in the Northern Great Plains - An Integrated Continental Record of the End of the Cretaceous. Geological Society of America Special Paper, vol. 361, pp. 297-327. http://dx.doi.org/10.1130/0-8137-2361-2.297

Labandeira, C.C., Phillips, T.L., 1996a. Insect fluid-feeding on Upper Pennsylvanian tree ferns (Palaeodictyoptera, Marattiales) and the early history of the piercing-and-sucking functional feeding group. Annals of the Entomological Society of America 89, 157-183. http://dx.doi.org/10.1093/aesa/89.2.157

Labandeira, C.C., Phillips, T.L., 1996b. A Late Carboniferous petiole gall and the origin of holometabolous insects. Proceedings of the National Academy of Sciences of the United States of America 93, 8470-8474.

Labandeira, C.C., Prevec, R. 2014. Plant paleopathology and the roles of pathogens and insects. International Journal of Paleopathology 4, 1-16. http://dx.doi.org/10.1016/j.ijpp.2013.10.002

Labandeira, C.C., Sepkoski, J.J., 1993. Insect diversity in the fossil record. Science 261, 310315. http://dx.doi.org/10.1126/science. 11536548

Labandeira, C.C., Tremblay, S.L., Bartowski, E.E., Hernick, L.V., 2013. Middle Devonian liverwort herbivory and antiherbivore defence. New Phytologist 202, 247-258. http://dx.doi.org/10.1111/nph.12643

Labandeira, C.C., Wilf, P., Johnson, K.R., Marsh, F., 2007. Guide to Insect (and Other) Damage Types on Compressed Plant Fossils (version 3.0). Smithsonian Institution. http://paleobiology.si.edu/pdfs/insectDamageGuide3.01.pdf 
Landsberg, J., 1989. A comparison of methods for assessing defoliation, tested on eucalypt trees. Austral Ecology 14, 423-440. http://dx.doi.org/10.1111/j.1442-9993.1989.tb01452.x

Louda, SM., 1982. Distribution ecology: variation in plant recruitment over a gradient in relation to insect seed predation. Ecological Monographs 52, 25-41. http://dx.doi.org/10.2307/2937343

MacKerron, D.K.L., 1976. Wind damage to the surface of strawberry leaves. Annals of Botany $40,351-354$.

Maskell, W.M., 1894. Further coccid notes: with descriptions of new species from New Zealand, Australia, Sandwich Islands, and elsewhere, and remarks upon many species already reported. Transactions of the New Zealand Institute 27, 36-75, pls. 1-7.

Mazía, C.N., Kitzberger, T., Chaneton, E.J., 2004. Interannual changes in folivory and bird insectivory along a natural productivity gradient in northern Patagonian forests. Ecography 27, 29-40. http://dx.doi.org/10.1111/j.0906-7590.2004.03641.x

McLoughlin, S., 2011. New records of leaf galls and arthropod oviposition scars in PermianTriassic Gondwanan gymnosperms. Australian Journal of Botany 59, 156-169. http://dx.doi.org/10.1071/bt10297

Meyer, J., 1987. Plant Galls and Gall Inducers. Gebrüder Borntraeger, Stuttgart.

Mitter, C., Farrell, B., Wiegmann, B., 1988. The phylogenetic study of adaptive zones: has phytophagy promoted insect diversification? American Naturalist 132, 107-128. http://dx.doi.org/10.1086/284840

Montañez, I.P., Poulsen, C.J., 2013. The Late Paleozoic ice age: an evolving paradigm. Annual Review of Earth and Planetary Sciences 41, 629-656. http://dx.doi.org/10.1146/annurev.earth.031208.100118

Naugolnykh, S.V., Ponomarenko, A.G., 2010. Possible traces of feeding by beetles in coniferophyte wood from the Kazanian of the Kama River Basin. Paleontological Journal 44, 468-474. http://dx.doi.org/10.1134/s0031030110040131 
Novokshonov, V.G., 1998. Chekarda-The Locality of Permian Fossil Plants and Insects. Permian University Press, Perm, Russia.

Oksanen, J.F. Blanchet, G., Kindt, R., Legendre, P., Minchin, P.R, O'Hara, R.B., Simpson, G.L., Solymos, P., Stevens, M.H.H., Wagner, H., 2013. Vegan: Community Ecology Package. R package version 2.0-10. http://CRAN.R-project.org/package=vegan

Opler, P.A., 1973. Fossil lepidopterous leaf mines demonstrate the age of some insect-plant relationships. Science 179, 1321-1323. http://dx.doi.org/10.1126/science.179.4080.1321

Pant, D.D., Srivastava, P.C., 1995. Lower Gondwana insect remains and evidences of insectplant interaction. In: Surange, K.R., Bose, M.D., Khare, P.K. (Eds.), Proceedings of the International Conference on Global Environment and Diversification through Geological Time. Society of Indian Plant Taxonomists, Allahabad, India, pp. 317-326.

Pinheiro, E.R.D., 2012. Specificity of leaf damage in the Permian "Glossopteris Flora": A quantitative approach. Review of Palaeobotany and Palynology 174, 113-121. http://dx.doi.org/10.1016/j.revpalbo.2012.01.002

Plumstead, E.P., 1963. The influence of plants and environment on the developing animal life of Karoo times. South African Journal of Science 54, 135-147.

Prevec, R., Labandeira, C.C., Neveling, J., Gastaldo, R.A., Looy, C.V., Bamford, M., 2009. Portrait of a Gondwanan ecosystem: A new late Permian fossil locality from KwaZulu-Natal, South Africa. Review of Palaeobotany and Palynology 156, 454-493. http://dx.doi.org/10.1016/j.revpalbo.2009.04.012

R Development Core Team, 2013. R: A language and environment for statistical computing. Vienna, Austria. Available from www.r-project.org (accessed September 1, 2014).

Rhoades, D.F., 1985. Offensive-defensive interactions between herbivores and plants: their relevance in herbivore population dynamics and ecological theory. American Naturalist 125, 205-238. http://dx.doi.org/10.1086/284338

Root, R.B., 1973. Organization of plant-arthropod association in simple and diverse habitats: the 
fauna of collards (Brassica oleracea). Ecological Monographs 43, 95-124.

http://dx.doi.org/10.2307/1942161

Rößler, R., 2000. The late Palaeozoic tree fern Psaronius—an ecosystem unto itself. Review of

Palaeobotany and Palynology 108, 55-74. http://dx.doi.org/10.1016/s0034-6667(99)00033-0

Rößler, R., Fiedler, G., 1996. Fraßspuren an permischen Gymnospermen-Kieselhölzern -

Lebenszeichen von Arthropoden im Oberrotliegend von Chemnitz. Veröffentlichungen des Museums für Naturkunde Chemnitz 19, 27-34.

Ruth, D.S., 1980. A Guide to Insect Pests in Douglas-fir Seed Orchards. Canadian Forestry Service and Pacific Forest Research Centre, Victoria, British Columbia.

Schachat, S.R., Labandeira, C.C., 2015. Evolution of a complex behavior in early ecosystems: The origin and initial diversification of foliar galling by insects during the Permian Period. The Science of Nature 102, 1-8. http://dx.doi.org/10.1007/s00114-015-1266-7

Schachat, S.R., Labandeira, C.C., Gordon, J., Chaney, D.S., Levi, S., Halthore. M.S., Alvarez, J., 2014. Plant-insect interactions from the Early Permian (Kungurian) Colwell Creek Pond, North-Central Texas: The early spread of herbivory in riparian environments. International Journal of Plant Sciences 175, 855-890. http://dx.doi.org/10.1086/677679

Schmidt, G., Zotz, G., 2000. Herbivory in the epiphyte, Vriesea sanguinolenta Cogn. \& Marchal (Bromeliaceae). Journal of Tropical Ecology 16, 829-839. http://dx.doi.org/10.1017/s0266467400001747

Scott, A.C., Taylor, T.N., 1983. Plant/animal interactions during the Upper Carboniferous. Botanical Review 49, 259-307. http://dx.doi.org/10.1007/bf02861089

Scott, A.C., Titchener, F.R., 1999. Techniques in the study of plant-arthropod interactions. In: Jones, T.P., Rowe, N.P., (Eds.), Fossil Plants and Spores: Modern Techniques. Geological Society, London, pp. 310-315.

Sharov, A.G., 1973. Morphological features and mode of life of the Palaeodictyoptera. In: BeiBenko, G.Y. (Ed.), Readings in the Memory of Nicolaj Aleksandrovich Kholodovskij. 
Nauka, Leningrad, pp. 49-63 (in Russian).

Shcherbakov, D.E., 2000. Permian faunas of Homoptera (Hemiptera) in relation to phytogeography and the Permo-Triassic crisis. Paleontological Journal 34, S251-S267 (Supplement).

Shcherbakov, D.E., 2008. On Permian and Triassic insect faunas in relation to biogeography and the Permian-Triassic crisis. Paleontological Journal 42, 15-31.

Shute, C.H., Cleal, C.J., 1987. Palaeobotany in museums. The Geological Curator 4, 553-559.

Sinclair, W.A., Lyon, H.H., Johnson, W.T., 1987. Diseases of Trees and Shrubs. Cornell University Press, Ithaca, N.Y.

Slater, B.J., McLoughlin, S., Hilton, J., 2012. Animal-plant interactions in a Middle Permian permineralised peat of the Bainmedart Coal Measures, Prince Charles Mountains, Antarctica. Palaeogeography, Palaeoclimatology, Palaeoecology 363-364, 109-126. http://dx.doi.org/10.1016/j.palaeo.2012.08.018

Srivastava, A.K., 1987. Lower Barakar flora of Raniganj Coalfield and insect/plant relationship. Palaeobotanist 36, 138-142.

Strong, D. R., Lawton, J. H., Southwood, S. R. 1984. Insects on Plants: Community Patterns and Mechanisms. Oxford University Press, Oxford, United Kingdom.

Stull, G.W., Labandeira, C.C., DiMichele, W.A., Chaney, D.S., 2013. The "seeds" on Padgettia readi are insect galls; Reassignment of the plant to Odontopteris, the gall to Ovofoligallites n. gen., and the evolutionary implications thereof. Journal of Paleontology 87, 217-231. http://dx.doi.org/10.1666/12-063r.1

Szwedo, J., Lapeyrie, J., Nel, A., 2015. Rooting down the aphid's tree - the oldest record of the Aphidomorpha lineage from Paleozoic (Insecta, Hemiptera). Systematic Entomology 40, 207-213. https://dx.doi.10.1111/syen.12099

Tabor, N.J., Montañez, I.P., Scotese, C.R., Poulsen, C.J., Mack, G.H., 2008. Paleosol archives of environmental and climatic history in paleotropical western Pangaea during the latest 
Pennsylvanian through Early Permian. Geological Society of America Special Paper 441, 291-304. http://dx.doi.org/10.1130/2008.2441(20)

Tabor, N.J., Romanchock, C.M., Looy, C.V., Hotton, C.L., DiMichele, W.A., Chaney, D.S., 2013. Conservatism of Late Pennsylvanian vegetational patterns during short-term cyclic and long-term directional environmental change, western equatorial Pangaea. Geological Society, London, Special Publications 376, 201-234. http://dx.doi.org/10.1144/sp376.14

Taylor, T.N., 1965. Palaeozoic seed studies: a monograph of the American species of Pachytesta. Palaeontographica Abteilung B, 1-46.

Thompson, J.N., 2013. Relentless Evolution. University of Chicago Press, Chicago. http://dx.doi.org/10.7208/chicago/9780226018898.001.0001

Tovar, J.T.M., Montiel, R.C., Bolaños, H.O., Yates III, H.O., Lara, J.F., 1995. Insectos Forestales de México. Universidad Autónoma Chapingo, Chapingo, México. 453 pp.

Turcotte, M.M., Davies, T.J., Thomsen, C.J.M., Johnson, M.T.J., 2014. Macroecological and macroevolutionary patterns of leaf herbivory across vascular plants. Proceedings of the Royal Society B 281: 20140555. http://dx.doi.org/10.1098/rspb.2014.0555

van Amerom, H.W.J., 1966. Phagophytichnus ekowskii nov. ichnogen. nov. ichnosp. eine Mißbildung infolge von Insectenfraß, aus dem spanischen Stephanien (Provinz Léon), Leidse Geologische Mededelingen 38, 181-184.

van Amerom, H.W.G., 1973. Gibt es Cecidien im Karbon bei Calamiten und Asterophylliten? In: Josten, K.-H. (Ed.), Compte Rendu Septième Congrès International de Stratigraphie et de Géologie du Carbonifère. Van Acken, Krefeld, pp. 63-83.

Vasilenko, D.V., 2007. Feeding damage on Upper Permian plants from the Sukhona River. Paleontological Journal 41, 207-211. http://dx.doi.org/10.1134/s0031030107020116 Vasilenko, D.V., 2011. The first record of endophytic insect oviposition from the Tatarian of European Russia. Paleontological Journal 45, 333-334. http://dx.doi.org/10.1134/s0031030111030154 
Vincent, J., 1990. Fracture properties of plants. Advances in Botanical Research 17, 235-287. http://dx.doi.org/10.1016/s0065-2296(08)60135-4

Waggoner, B.M., Poteet, M.F., 1996. Unusual oak leaf galls from the middle Miocene of northwestern Nevada. Journal of Paleontology 70, 1080-1084.

Wappler, T., Kustatscher, E., Dellantonio, E., 2015. Plant-insect interactions from Middle Triassic (late Ladinian) of Monte Agnello (Dolomites-N-Italy) —initial pattern and response to environmental perturbations. PeerJ 3, e921. http://dx.doi.org/10.7717/peerj.921

Weber, H., 1930. Biologie der Hemipteren: eine Naturgeschichte der Schabelkerfe. Julius Springer, Berlin. http://dx.doi.org/10.1007/978-3-642-50844-8

Weintraub, J.D., Cook, M.A., Scoble, M.J., 1994. Notes on the systematics and ecology of a fernfeeding looper moth, Entomopteryx amputata (Lepidoptera: Geometridae). Malayan Nature Journal 47, 355-367.

Wilf, P., Labandeira, C.C., 1999. Response of plant-insect associations to Paleocene-Eocene warming. Science 284, 2153-2156. http://dx.doi.org/10.1126/science.284.5423.2153

Wilf, P., Labandeira, C.C., Kress, W.J., Staines, C.L., Windsor, D.M., Allen, A.L., Johnson, K.R., 2000. Timing the radiations of leaf beetles: hispines on gingers from latest Cretaceous to Recent. Science 289, 291-294. http://dx.doi.org/10.1126/science.289.5477.291

Williams, M.R., Abbott, I., 1991. Quantifying average defoliation using leaf-level measurements. Ecology 72, 1510-1511. http://dx.doi.org/10.2307/1941126

Wilson, J., 1980. Macroscopic features of wind damage to leaves of Acer pseudoplatanus L. and its relationship with season, leaf age, and windspeed. Annals of Botany 46, 303-11. 
Figure 3

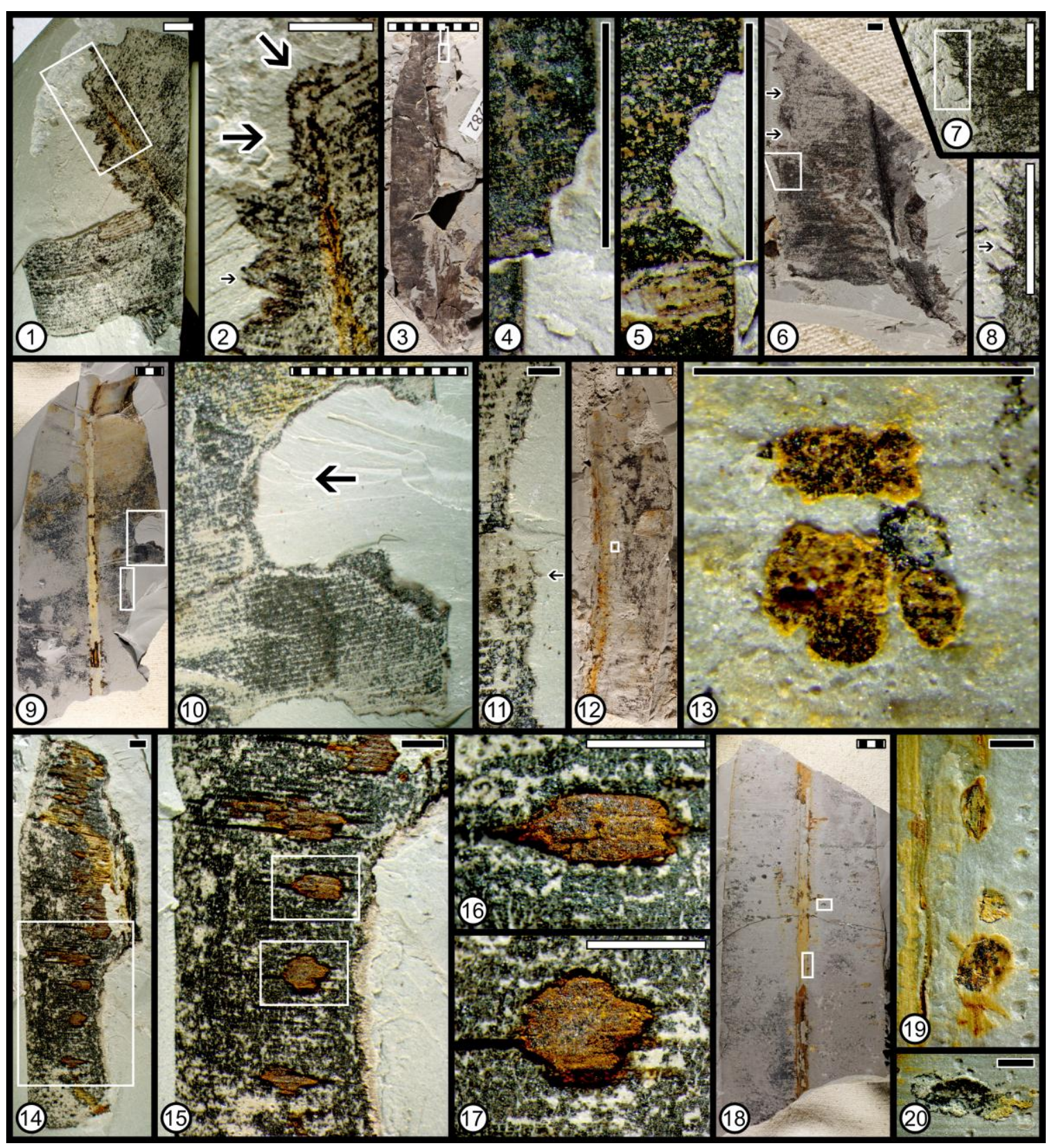


Figure 4

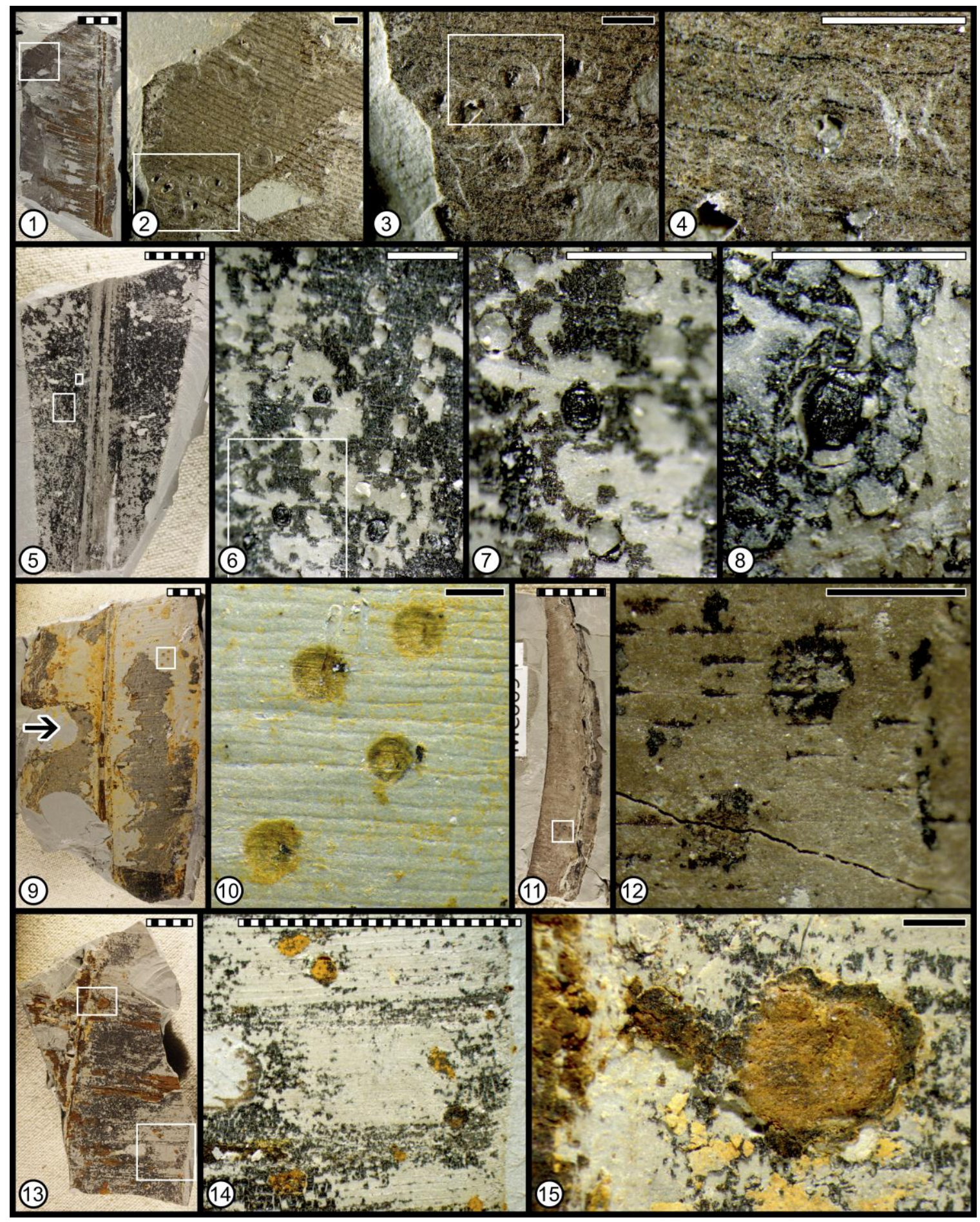


Figure 5

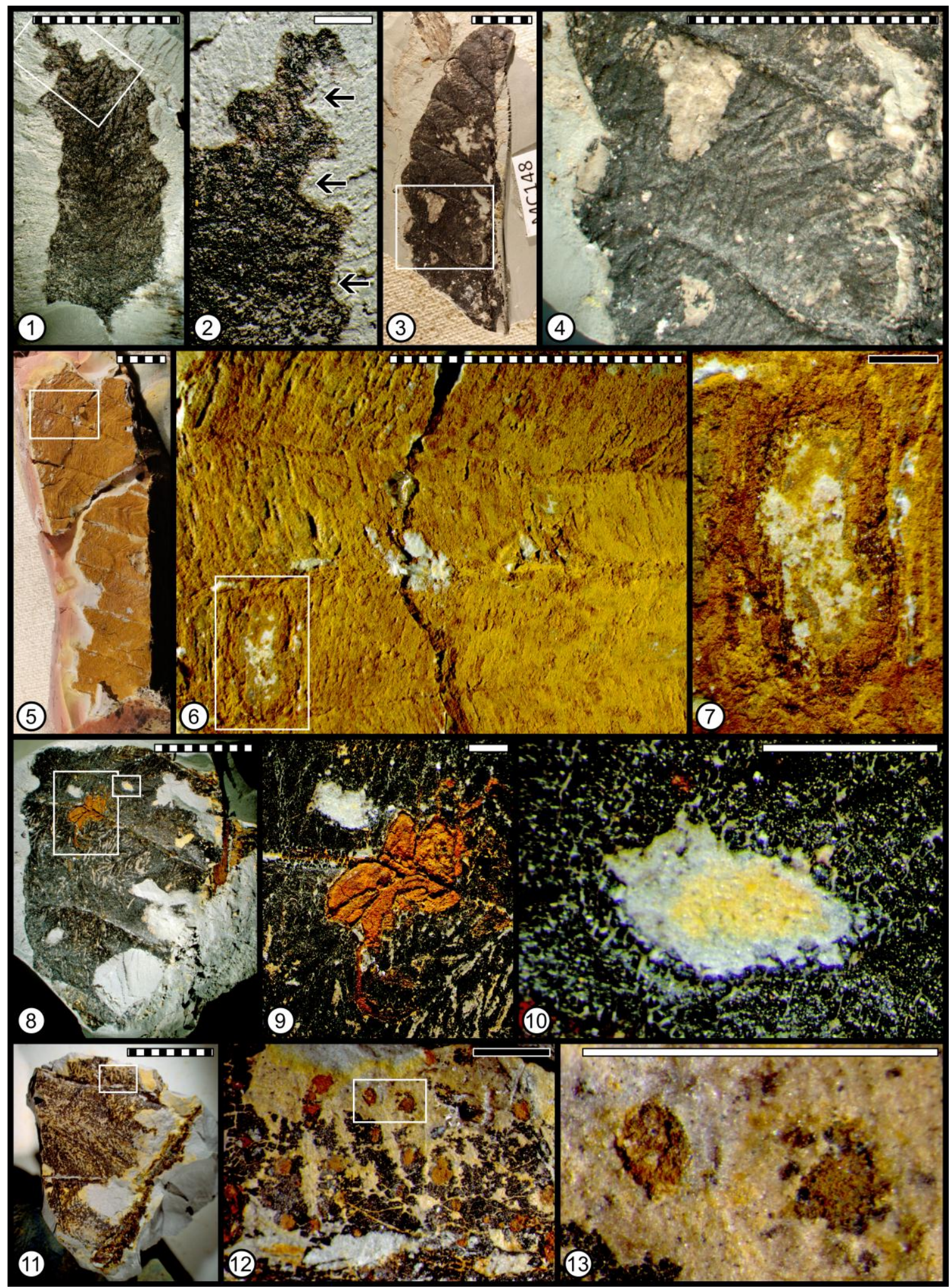


Figure 6

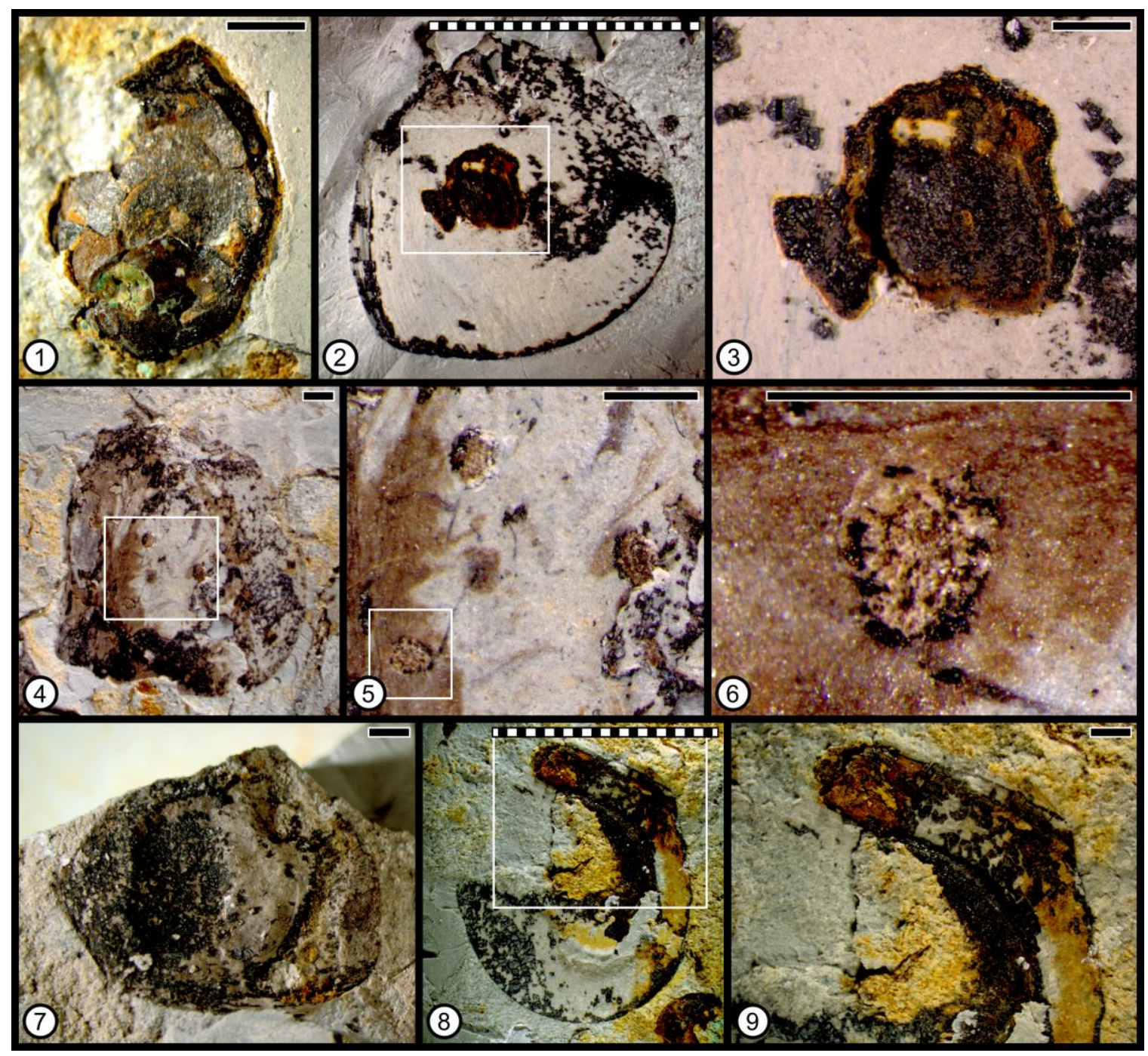

